\title{
Superintendent efficacy investigation of a six -component leadership framework for developing effective learning environments
}

Frank D. Devono

West Virginia University

Follow this and additional works at: https://researchrepository.wvu.edu/etd

\section{Recommended Citation}

Devono, Frank D., "Superintendent efficacy investigation of a six -component leadership framework for developing effective learning environments" (2009). Graduate Theses, Dissertations, and Problem Reports. 2919.

https://researchrepository.wvu.edu/etd/2919

This Dissertation is protected by copyright and/or related rights. It has been brought to you by the The Research Repository @ WVU with permission from the rights-holder(s). You are free to use this Dissertation in any way that is permitted by the copyright and related rights legislation that applies to your use. For other uses you must obtain permission from the rights-holder(s) directly, unless additional rights are indicated by a Creative Commons license in the record and/ or on the work itself. This Dissertation has been accepted for inclusion in WVU Graduate Theses, Dissertations, and Problem Reports collection by an authorized administrator of The Research Repository @ WVU.

For more information, please contact researchrepository@mail.wvu.edu. 


\title{
SUPERINTENDENT EFFICACY
}

INVESTIGATION OF A SIX-COMPONENT LEADERSHIP FRAMEWORK FOR

DEVELOPING EFFECTIVE LEARNING ENVIRONMENTS

\author{
by \\ Frank D. Devono \\ Dissertation submitted to the College of Human Resources and Education \\ at West Virginia University \\ in partial fulfillment of the requirements \\ for the degree of
}

\author{
Doctor of Education \\ in \\ Curriculum and Instruction
}

\author{
Approved by: \\ Joy Faini Saab, Ed.D., Chairperson \\ Patricia Obenauf, Ed.D. \\ Perry Phillips, Ed.D. \\ Richard Hartnett Ed.D. \\ Sebastian Diaz Ph.D., J.D. \\ Mark Manchin, Ed. D.
}

Human Resources \& Education

Morgantown, West Virginia

2009

Keywords: Effective Learning Environment; Superintendent Efficacy

Copyright 2009 Frank D. Devono 


\section{Abstract \\ SUPERINTENDENT EFFICACY \\ INVESTIGATION OF A SIX-COMPONENT LEADERSHIP FRAMEWORK FOR DEVELOPING EFFECTIVE LEARNING ENVIRONMENTS}

\section{by Frank D. Devono}

This study, using the Superintendent Efficacy Questionnaire (Devono, Diaz \& Callejo Perez, 2008), compared 413 West Virginian K-12 superintendents', principals' and teachers' perceptions of 6 superintendent leadership components: staff development administration, communication of mission, curriculum/instruction expertise, collaboration with the school board, consensus-building ability, and political bearing.

A Kruskal-Wallis test produced significant results for 2 components: the superintendent's ability to (a) clearly articulate a mission that establishes direction/priorities for the system $(\chi 2=10.99 ; d f=2 ; \mathrm{p}=0.004)$, and (b) work with the local school within the budget $(\chi 2=7.260$; $d f=2 ; \mathrm{p}=0.027)$. Related sample $t$ tests resulted in no significant differences in teachers' perceptions of their superintendent and their principal's perceptions of the superintendent. 


\section{Dedication}

The author wishes to dedicate this dissertation to my parents, the late Gabriel and Ethel Devono, who exemplified the value of education. Even though they never had the chance to attend college, the value they placed on education for all three of their children — as a way to better themselves - has been the motivation of my professional life's work. 


\section{Acknowledgments}

The author wishes to extend my profound thanks to all who have played a direct and indirect role with the completion of this dissertation. Their assistance and cooperation were vital each step of the way as I completed this research project.

To my committee chair, Dr. Joy Faini Saab, for her willingness to support and encourage me as I began this endeavor. The discussion and confidence given to me from the onset of the endeavor was invaluable.

To my committee members, Drs. Sebastian Diaz, Patricia Obenauf, Perry Phillips, Richard Hartnett, and Mark Manchin, I would like to express my deepest gratitude for your support both professionally and personally.

I would like to acknowledge Drs. Sebastian Diaz and David Callejo for their guidance and assistance in the development of the Superintendent Efficacy Questionnaire. Dr. Diaz's expertise with the interpretation of statistical data molded the questionnaire from raw facts to rich information yielding a wealth of knowledge.

I want to express my thanks to the superintendents, principals, and nationally certified teachers who took time from very busy schedules to complete the questionnaire.

I want acknowledge the Monongalia County Board of Education members President Nancy Walker, Vice President Joe Statler, members Dr. Barbara Parsons, Dr. Clarence Harvey, Mike Kelly and past member Steve Cook for their support and encouragement. Without this support I would not have been able to complete this daunting task.

To my colleagues and friends at the Monongalia County Board of Education office whose words of encouragement and willingness to help was always available. 
My sincerest gratitude to Pam Deering for all of her help, expertise and assistance throughout this writing process.

To my family and friends, sister Ethel, and brother Gabe who have been cheerleaders throughout this journey.

To my wife Kay, my strongest supporter, I express my deepest gratitude. As we walked this road together side by side I thank you for all of your support and encouragement. You believed in me and supported this life's work from the beginning. I will eternally be grateful.

To my children, Frank Jr. and Rebecca; Rachael and Andrew, whose fight with cancer taught our family about life and love; Gabriel and Quinn and granddaughters Emily and Sophia, I started this journey aspiring to be your role model as a lifelong learner. Instead each of you has become my inspiration making us all stronger and committed to one another as a family. 
Table of Contents

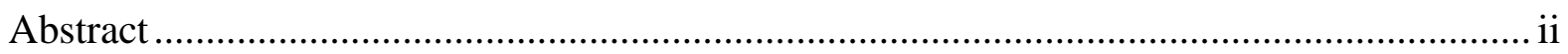

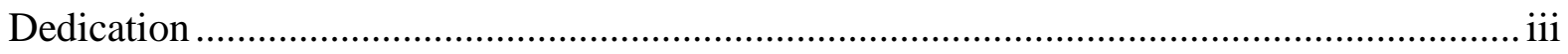

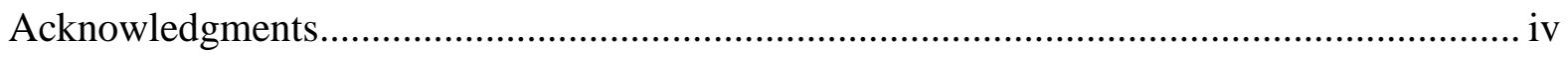

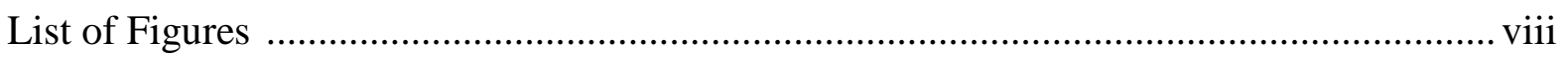

List of Tables .......................................................................................................... ix

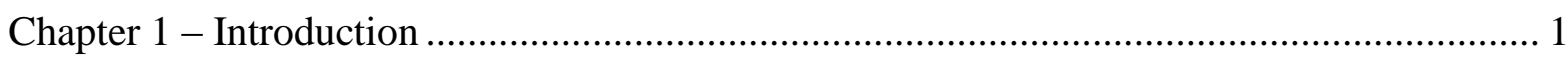

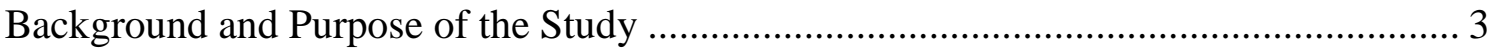

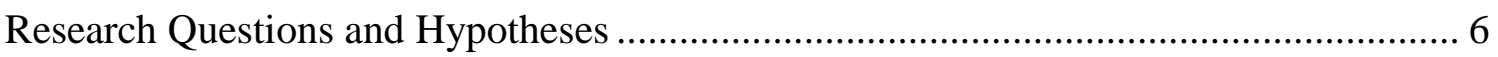

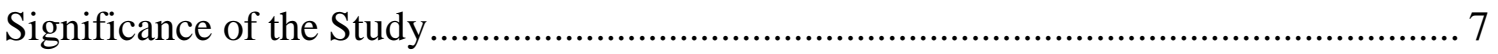

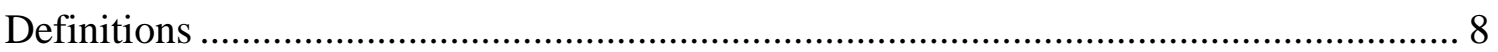

Chapter 2 - Literature Review ........................................................................... 10

Historical Perspective: Evolution of the Superintendent Position................................ 10

Superintendent Leadership Components ….................................................... 16

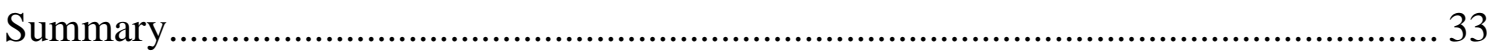

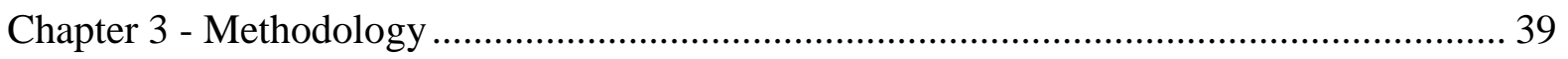

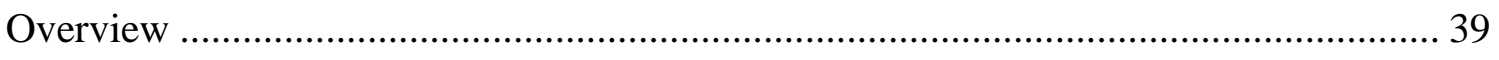

Statement of the Problem .................................................................................... 39

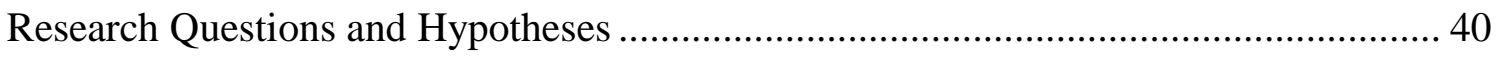

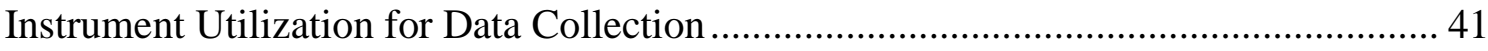

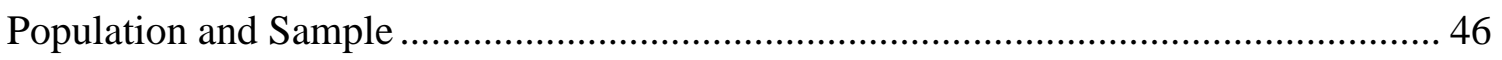

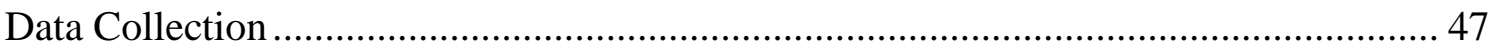




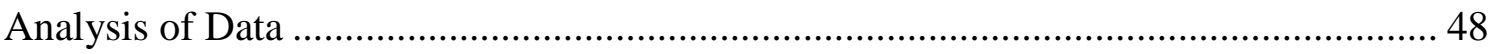

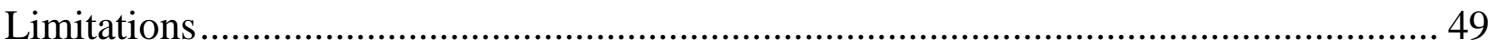

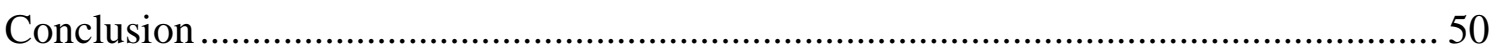

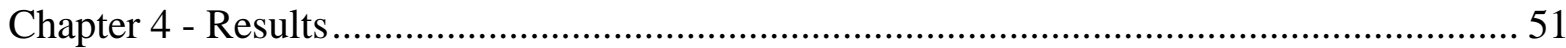

Relative Importance of Leadership Components ................................................. 52

Comparison of Teachers' and Principals' Perceptions of the Superintendent ............... 58

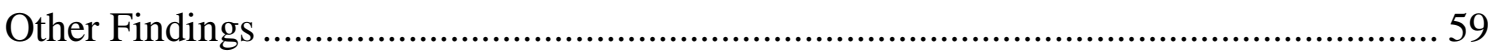

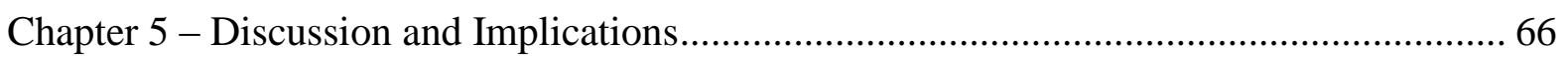

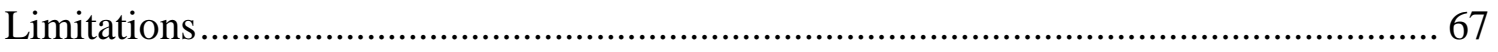

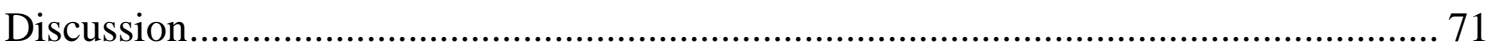

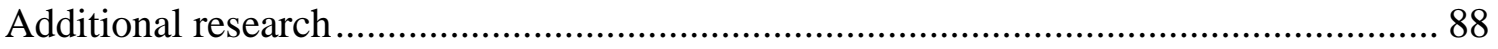

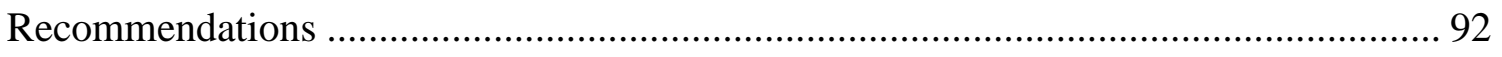

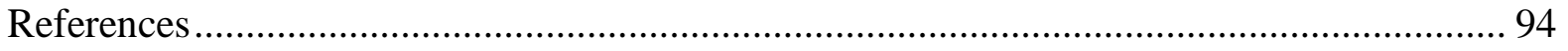

Appendix A - Superintendent Efficacy Questionnaire................................................ 99

Appendix B - Descriptive Statistics .................................................................... 104 


\section{List of Figures}

Figure 1. Evolutionary development of the role of the superintendent. ............................... 15

Figure 2. Superintendent six-component leadership framework......................................... 38 


\section{List of Tables}

Table 1. Kruskal-Wallis Test Results .......................................................................... 54

Table 2. Leadership Subscale Mean Rank by Respondent Role ..................................... 55

Table 3. Leadership Subscale Mean Ranking by Respondent Role .................................. 57

Table 4. Paired T Test Results for Teachers and Principals .......................................... 59

Table 5. Sample Distribution by Role and Gender ...................................................... 61

Table 6. Sample Distribution by Role and Degree Held ................................................. 61

Table 7. Sample Distribution by Role and School Type .............................................. 62

Table 9. Leadership Components' Relative Importance Ranking by Respondent Role ........ 72

Table 10. Leadership Components' Relative Importance Ranking by Total Mean ............... 80 


\section{Chapter 1 - Introduction}

The improvement of public education has become a centerpiece of America's political agenda. Starting with the National Commission on Excellence in Education's 1984 report, $A$ Nation at Risk: The Imperative for Educational Reform, and more recently with the No Child Left Behind Act of 2001, policy makers have grappled with how to bring about significant reform in public schools (Paine, 2006).

Improvement of public education is also a focus of state politics. In West Virginia, a state initiative, $21^{\text {st }}$ Century Skills, is driving improvement of West Virginia schools by introducing significant changes in the education system. The West Virginia State Board of Education has established a model framework for the $21^{\text {st }}$ Century Skills. Three major components of the model are strong core beliefs, system-wide strategies, and use of a systemic continuous improvement process (Paine, 2006). These components appear to be commonalities among high performing school systems and classrooms. School systems are expected to embark on the development of skills that challenge teachers and administrators to prepare the learner for the twenty-first century. The expectation is that the county superintendent has the ability to lead this initiative, thereby creating an effective learning environment.

In July of 1966, Coleman reported in The Equal Educational Opportunity Survey that family background was a major determinant of student achievement (Lezotte, n.d.). This report led to the creation of compensatory education and programs that dominated school improvement. The Effective Schools Movement (Lezotte, n.d.), which supports the belief that all children can learn and that schools control the factors necessary to assure student mastery, drew its beginning from this report. 
School superintendents play a major role in reform efforts within a school district. One of the high expectations of an effective superintendent of schools is to create the best possible learning environment for the students in the school district. As the educational leader for the district, the superintendent is faced with the difficult challenge of cultivating and sustaining learning under a condition of rapid change (Fullan, 2001). The superintendent is one building block in the construction of the leadership of a learning-rich environment.

A vital role of the superintendent is to create within the school system an opportunity for employees to develop an effective learning environment. How do teachers and principals view the superintendent's efforts to provide such opportunities? Do superintendents effectively work with school boards to impact the learning environment within the classroom? Do superintendents communicate the mission of the system that is supported by the budget? Are superintendents building consensus among the educators as they demonstrate their own knowledge of curriculum? Can superintendents work effectively with the political elements in the community to effect positive outcomes within the classroom?

The role in which the superintendent served from the inception of the position was one of a teacher, an instructional leader. Later, this role changed to more of a business manager (CEO) than educator. Some educators think that the superintendent's position is removed from the classroom and that the superintendent is unable to effect change (Rallis, Tedder, Lachman, \& Elmore, 2006). Has a businessman's persona encouraged teachers and principals to work independently from superintendents as new initiatives are introduced?

Since research indicates that leadership should be from the bottom up as change is introduced (Johnson, 1996), how knowledgeable should a superintendent be regarding teaching and curriculum? If the literature indicates consensus building is important to create an effective 
learning environment (AASA, 1993), how can a superintendent build consensus and communicate that message to the employees, directly impacting the classroom? Can the superintendent effectively use his/her political influence to resolve conflicts among stakeholders? This study examined superintendents', principals' and teachers' perceptions of superintendent efficacy in six leadership areas.

The remainder of this chapter relates the background and purpose of the study, states the research questions, describes the significance of the study and lists definitions relevant to the study. Chapter 2 portrays an historical perspective of the changing role of the superintendent and culls from the literature a framework of six key superintendent leadership components upon which the survey instrument for this study was developed. Chapter 3 describes the methodology of the proposed dissertation study. Chapter 4 gives the study's results, and Chapter 5 elaborates on the study's results and implications.

\section{Background and Purpose of the Study}

In response to the need for change, superintendents must take the lead in establishing effective learning environments. School systems spend hundreds of thousands of dollars yearly for research-based staff development sessions that promote teaching and curriculum strategies for professional educators to include in their planning and teaching. Is this retooling of education effective? Through this annual expenditure of funding, is the superintendent creating an effective learning environment? After the money has been spent and the training has been completed, do teachers implement these new strategies as they close the doors to their classrooms?

I believe the role of the principal and teacher is crucial to any educational initiative introduced into the curriculum. How do these major players perceive the superintendent's role and expectations to implement change? How do the superintendents themselves perceive their 
own effectiveness in implementing change within the school system? Do teachers and principals have their own ideas and strategies, which are different from the superintendent's, as to what should be implemented in the classroom to promote learning? Do teachers and administrators believe staff development sessions are effective?

Since the leadership role of the superintendent within the educational community has an impact on the learning environment, how can a superintendent assess the implementation of new educational initiatives? Can the superintendent affect excellence within the classroom? What roles does the superintendent perform that can have a direct or indirect influence in the classroom?

The Executive Leadership (2007) identifies eight keys to leadership greatness: (a) maintain absolute integrity, (b) know your stuff, (c) declare your vision, (d) show uncommon commitment, (e) expect positive results, (f) take care of your people, (g) put duty before self, and (d) stand out in front. These keys are examples of what a leader in the business community should possess to be successful.

I believe these characteristics are also effective indicators within the educational community. Superintendents must maintain integrity and be knowledgeable of the curriculum to effect change within the school system and classroom. When I have visited classrooms or attended staff development sessions within my county school system, teachers have expressed their opinions concerning the effectiveness of our district's attempts to create an effective learning environment. A sentiment expressed by teachers is that we (administrators) are so far removed from the classroom that we do not understand the challenges of the classroom teacher. Principals have expressed their views to me that the job they perform is all encompassing and 
that it is difficult to concentrate on only one responsibility such as curriculum when discipline or plant management present more immediate concerns.

Throughout my career, and most recently as an acting superintendent, I have found that most decisions made by a superintendent that are recommended to the board for approval will directly and/or indirectly impact the classroom and school. Each decision will cause benefit or concern for students and/or employees.

According to the literature, principals are instructional leaders (Fullan, 2008). How effective do teachers think their superintendents are in creating an effective learning environment? Do teachers perceive their own role as change agents, separate from administrators within the building or district office? Do principals play a major role in the implementation of new initiatives within the classroom? Many superintendents control budgets and curriculum initiatives with local school board authorization; is this enough to create an effective learning environment? What about consensus building? Is it crucial among teachers, administrators and superintendents to effectively implement change? Should the superintendent manage the political landscape to implement curriculum initiatives?

I expected that this study would indicate that superintendents do believe that their decisions directly impact the learning environment and that administrators believe that staff development sessions, if developed with the teachers and principals, will directly impact the learning environment.

I believed that the teachers' views would be somewhat different, that teachers would indicate that they are removed from the decision-making process and yet are asked to implement teaching strategies that they do not fully support. I expected that teachers would also indicate that administrators do not fully understand the classroom and that the teachers know best when it 
comes to meeting the needs of the students. I believed that this study would suggest that teachers want to be involved and want to be a part of the decision making process. I thought teachers would rate consensus building as an integral part of creating an effective learning environment.

A variety of criteria exist for assessing leadership quality of K-12 school superintendents. Any assessment used needs to consider various perspectives that impact the overall perceptions of the superintendent's efficacy: (a) the superintendent's self-perception of his/her efficacy, (b) principals' perceptions of their superintendents' efficacy, and (c) teachers' perceptions of their superintendents' efficacy. This study assessed the leadership qualities of the superintendent, identifying strengths and limitations of leadership theory by examining the strengths and limitations of a survey instrument designed around that theory. Therefore, this study explored the role of the superintendent in developing effective learning environments.

\section{Research Questions and Hypotheses}

Two main research questions comprise the basis for this exploration of the superintendent's role in developing effective learning environments:

Research Question \#1 (RQ1): How do superintendents,' principals', and teachers' perceptions differ with respect to the relative importance of multiple roles required of effective superintendents?

$\mathrm{H}_{\mathrm{o}}$ : There is no statistically significant difference in how superintendents, principals, and teachers, perceive the relative importance of the components that comprise leadership efficacy among superintendents.

$\mathrm{H}_{\mathrm{a}}$ : There is a statistically significant difference in how superintendents, principals, and teachers perceive the relative importance of the components that comprise leadership efficacy among superintendents. 
Research Question \#2 (RQ2): Is there a statistically significant difference when comparing teachers' perceptions of their superintendent with the perceptions of their respective supervising principal?

$\mathrm{H}_{\mathrm{o}}$ : There is no statistically significant difference when comparing teachers' perceptions of their superintendent with the perceptions of their respective supervising principal.

$\mathrm{H}_{\mathrm{a}}$ : There is a statistically significant difference when comparing teachers' perceptions of their superintendent with the perceptions of their respective supervising principal.

\section{Significance of the Study}

Are superintendents effective in developing an effective learning environment? Can they directly or indirectly effect changes within the classroom that will positively impact instruction? Do the decisions of the superintendent create or hinder an effective learning environment?

This study focused on the superintendent's efficacy in developing an effective learning environment, in particular, through superintendents', principals' and teachers' perceptions of a theory-based framework of superintendent leadership components. The study yielded a newly developed instrument, Superintendent Efficacy Questionnaire, to measure perceptions with respect to that leadership components framework. In doing so, the study contributes a tool that can potentially clarify some strengths and limitations of leadership theory, thereby helping to connect theory and practice of leadership principles in K-12 schools. The findings of the study can potentially assist acting superintendents with decision-making regarding what should be considered as they direct instruction to create an effective learning environment. 
As instructional staffs throughout the country are retooling, superintendents will need to be aware of what teachers and administrators believe most effect change in the classroom. This study sheds some light on what superintendent leadership components are perceived as important by teacher and principals; it can help educators understand the superintendent's ability to effect change in the classroom through staff development administration, articulating a mission, working with the school board, demonstrating knowledge of curriculum and teaching, and through concentrated efforts, such as consensus building, in working with principals and teachers to bring about change. The study also explores the role educational politics play in the decision making process on the local level.

\section{Definitions}

Core Beliefs:

A system's foundational values that identify behaviors which the system is committed to acting upon. Core beliefs define how individuals act toward one another; they answer the question, what do we stand for? (Lezotte, n.d.)

Effective Schools: Schools that are successful in educating all students, regardless of their socioeconomic status or family background.

Efficacy The power to produce an effect (Mish, 1997)

High Expectations: The curriculum staff believes and demonstrates that all students can obtain mastery of the school's essential curriculum.

Learning Rich Environment: $\quad$ A setting in which teachers allocate a significant amount of classroom time to instruction in the essential curricular 
Mission:

No Child Left Behind:

Student Achievement/Mastery:

System wide Strategies:

$21^{\text {st }}$ Century Skills: areas and students are actively engaged in whole-class or large group, teacher-directed, planned learning activities. A short statement that identifies what a school system seeks to accomplish (Paine, 2006).

United States Department of education Public Law 107-110 has become known as No Child Left Behind (NCLB). This law promotes a uniform curriculum for all children. State governments are responsible for enforcing this law.

Pupil attainment of the essential learning objectives. Attainment progress is measured and monitored frequently to improve the individual student behaviors, performances, and to improve the curriculum.

The long-term plan of action a school system selects to achieve its goals.

Systemic Continuous Improvement: Professional development for and by strategic planning team collaboration time, data management systems, time for improvement teams, support for learning communities. A learning model, which seeks to assure that learners will have the knowledge and skills to prosper in school and within the workforce in the $21^{\text {st }}$ century. 


\section{Chapter 2 - Literature Review}

The role of the superintendent has changed drastically over the last 150 years. Superintendents did not always serve as instructional leaders as they currently do. In order to understand the role the superintendent plays today, I first examine the evolution of the superintendent's role in American education through a detailed history of the superintendency. Then I explore more current roles of the superintendent, addressing six particular leadership components of an effective superintendent through the integration of personal critical narrative and the literature about the superintendent.

\section{Historical Perspective: Evolution of the Superintendent Position}

It is important to examine the position of the School Superintendent from a historical point of view. This chapter examines the social context that encompasses the superintendent position by using the idea that "Superintendents are dream builders for America's children" (AASA, 1993). The pressure to require excellence within our schools demands that superintendents meet the needs of all the children in their schools. In Principles of Curriculum and Instruction, Ralph Tyler (1947) begins by stating that all curriculums must be student centered. Since the Office of the Superintendent embodies an esoteric yet practical idea of high educational standards, the questions explored in this study have to relate to the ability of the superintendent to effect change (Tyler).

The American school system, having sprouted from the needs of small New England towns to educate their people, has existed for about 200 hundred years. Elected governmental bodies referred to as selectman or grand jurymen administered early schools. As school governance changed and student population increased, supervision of schools also changed, through implementation of "visiting committees" or what we know as school boards (Griffiths, 
1966). The first Office of the Superintendent was established in Massachusetts in 1842 and was held by Horace Mann. At that time, superintendent positions were appointed; however, it took about 60 years for the appointment of superintendents to manage school systems to become a common practice among cities in the United States.

The evolution of the superintendent position, according to Griffiths (1966), took place in three stages. From 1837-1910, the role of the superintendent ranged from instructor and board of education advisor to an executive officer of the board with much broader responsibilities. When the duties of part-time board members - supervising teachers and purchasing supplies_-became too cumbersome, school boards began to appoint superintendents to complete these tasks. From 1910-1945, the role of superintendent as businessman emerged. The main focus was one of emphasizing efficiency in the operation of the school system. Educational decisions were based on an educational perspective with instruction being a secondary role (Griffiths). In the 1920s, school reformers wanted school systems to be managed like corporations, and they worked the political machine for smaller school boards comprised of elected officials from businesses and the professions. Unfortunately, these elected representatives from the business community had political ties that sometimes resulted in favors for board members, causing superintendents and board members to be at odds with one another. The resulting distaste for politics among educational leaders played a role in the professionalizing of the superintendency and in shielding the superintendent from unwanted influences (Cuban, 1985). The professional school administrator that we see today began to emerge around 1945. Researchers have intensely studied the role of the superintendent to explore issues related to the leadership of the superintendent and how the superintendent position functions within the school system (Griffiths). 
In the earliest stage, superintendents were part-time elected school officials. Their responsibilities consisted of supervising and hiring teachers and support staff such as custodians. These earliest of superintendents kept records, taught teachers, and prepared examinations to administer to students. The purchasing of supplies, such as pencils, textbooks, and coal, was another fundamental task assigned to the superintendent's position (Cuban, 1985).

The industrial age and Fredrick Taylor's model of scientific management contributed to the second stage of the evolution of the role of the superintendent. Schools' principal organizational characteristics became hierarchical, similar to the organization of factories of the industrial era. Teachers were considered workers in an educational assembly line, students were products, and principals the foreman (Nelson, 1974). The superintendent in this same model was the chief executive, and the board of education represented the taxpayer, who was the shareholder (Doyle \& Hartle, 1985). In fact, the language and practices used in managing the factory made its way into the schools. The person in charge of the floor of the factory was known as the Superintendent; bells and whistles were used to signify time and changes.

Change was prevalent in the third stage of evolution of the superintendent role that began in the mid-1940s. Superintendents faced expectations of increased accountability from the business community, and the role politics played in the decision-making by board members created change. In addition, social and economic issues such as declining population, economic recession, and the civil rights movement brought change. The balancing of school budgets, losing students, losing funding, and facing the responsibility of dealing with the needs of all students increased challenges faced by the superintendent. The inability and/or unwillingness to adequately cope with these changes led to some of the historically highest turnover rates of superintendents in the 1960s. 
From an inauspicious beginning, the role of the superintendent has grown to one of responsibility and authority (Griffiths, 1966). However, the true decision-making authority within the school system lies with the school board, which is comprised of elected officials. The superintendent only makes recommendations; the final decision is relegated to a majority of school board members.

Today, as we try to identify the role of the superintendent, reviewing the past allows us to parallel the development of the school superintendency. As school systems divided into gradesfrom the one-room schoolhouses where the superintendent was teacher, principal, and custodian — and developed into local districts, the superintendent's role changed. These larger school systems changed the role of the superintendent from a teacher to an administrator who was responsible for creating curriculum that could be implemented throughout the school district (Kowalski, 1999). Today the position of superintendent of schools is one of the most important positions in the American school system: the superintendent deals with curriculum, instruction, students, personnel, legal issues, and social issues. Today the work of the superintendent is more political than it was in the past, as the work of the superintendent is tied directly to the work of the school board, as well as to federal and state legislation that affects schooling.

The superintendent position has become engendered by its history, from the remnants of the three unique stages, to the impact of WWII, growth in graduate education and the Civil Rights Movement. In my own experience, I have seen the superintendent's position range from being a position of absolute power in decision making to being a position of collaboration with teachers and administrators. As an educator, I feel empowered when included in the decision making regarding school and system wide initiatives. As a teacher, I felt less empowered to make decisions concerning classroom instruction because county or state level administrators 
prescribed the curriculum, and teachers were expected to implement the curriculum. My only decision was to choose how I would deliver the curriculum. As a principal, I was able to seek permission from the superintendent to implement ideas and educational initiatives that I had read about or had observed at staff development sessions. My role as a school administrator made it easier to build consensus among the staff to implement new initiatives. As a superintendent, the challenge of trying to build consensus within all schools and to meet the needs of professional organizations makes it more difficult to implement change. I have found that simply wanting a new initiative implemented and providing staff development sessions is not enough. I also understand the school board makes the final decision; however, I know many board members seek the input of those employees who will be implementing the programs before making a final decision.

Seeing how the superintendency has evolved to over the last 150 years helps one realize that "the development of the role of the superintendent was important in the evolution of the hierarchical educational organization. The primary reason for creating the position was to have a person work full time at supervising classroom instruction and assuring uniformity in the curriculum" (Joel Spring, as cited in Kowalski, 1999).

Figure 1 highlights the historical perspective of the many roles of the superintendency from its inception until today. The base under the pyramid symbolizes graphically the strength of the leadership role played by teachers, principals and superintendents as change is presented to create a learning rich environment. 


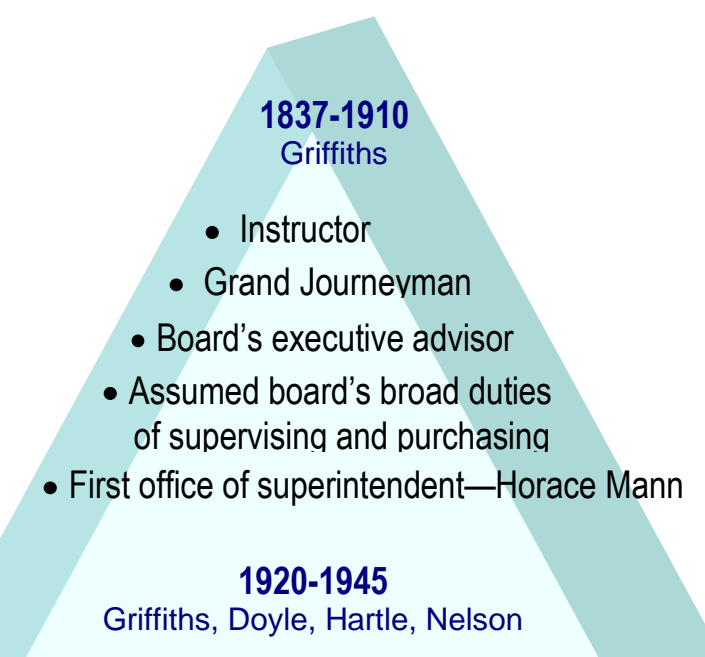

- Business minded

- Emphasis on efficient operation

- School reformers promote corporate management

- instructional perspective secondary to business model

- Political implications promote elected officials on school boards

\section{5-present}

Griffiths, Doyle, Hartle, Nelson, Ravitch

- Dynamics of politics

- Increased accountability

- Leadership issues studied by researchers

- Business community influence on school operations

- Pressures of economics, declining enrollments, funding

- Social and economic issues resulting from board decisions

- Emerging leaders come from business rather than educational arena

- Large system expectation-administrator responsible for creating curriculum

- Leaders placing more emphasis on accountability and production than on students

\section{LEADERSHIP}

Johnson, Fullan, Glass, AASA Cuban, Herman \& Stephens, Cunningham

- Bottom-up leadership as change is introduced

- Difficulty in cultivating and sustaining learning under rapid-change conditions

- Superintendent-leader central to creating effective learning environment

- Superintendent role requires bold, creative energy with vision to promote social change and diversity

- Instructional management promoting student performance is most important leadership in school system

- Superintendent must develop instructional leadership by creating effective leaders.

- Need to delegate principal autonomy authority, responsibility and support from board and central office

- All must lead by managing and manage by leading

- Leadership is the exercise of influence

Figure 1. Evolutionary development of the role of the superintendent. 
As the role of the superintendent continues to evolve, many programs are being introduced into the educational setting to train "urban superintendents". The business community continues to have input on how the school system should operate. Some emerging leaders have not practiced their skills in the schools; they have not taught, nor have they served in the capacity as a principal. These individuals may lack understanding and knowledge of education and may be so concerned about accountability and meeting production goals that they forget about the student. These types of situations can destroy learning (Ravitch, 2007).

The beginnings of the superintendent role depict the role as a teacher of many things in small settings - including teaching children and principals — and as one of fiscal management, as the superintendent managed many schools. Presently the role of the superintendent looks to replace the educator with business executives with little or no educational ties.

As school systems evolved, the superintendent's role as a teacher who could make a direct impact within the classroom changed. As school districts encompassed larger geographic regions and grew in student population, was the superintendent removed from the classroom and placed in the business office? Did this growth take the leader away from the original intention of a small school and community, that s/he have direct involvement in the classroom? Has the business model demanded efficiency to the point that one individual is to be accountable for all things within the educational system?

\section{Superintendent Leadership Components}

Today, serving in a vastly different role than in the past, the superintendent grapples with how to develop an effective learning environment. In that grappling, one might consider the role and knowledge of curriculum a superintendent must have to accomplish this development within a school system; or one might consider the political stakeholders and decision makers who have 
the authority or autonomy to help create this learning environment. Another issue is to consider who has the ability to directly influence the instructional setting. Instructional management that improves student performance may be the most important form of leadership within a school system (Cuban, 1985).

Changes in the school system should involve the superintendent. This leadership position is at the center of efforts to create an effective learning environment (Glass, 1992). The quality of America's schools depends on the effectiveness of school superintendents. The superintendent position requires a bold, creative, energetic and visionary individual who can deal with social change and diverse school populations (AASA, 1993).

As the instructional leader of the school district, the superintendent must strive to develop positive relationships among the staff within the county and specifically, within the schools. The nature of these relationships within the school "has a greater influence on the character and quality of that school and on student accomplishment than anything else" (Barth, 2006). Schools do make a difference!

Leaders within a school system daily encourage change as the system evolves through collective understanding, thinking, and action that result from school-wide engagement (York \& Barr, 2001). National accountability for improved academic performance of America's school children continues to press school systems to meet standards or face sanctions. Boleman and Deal (1997) identify four frames that people rely on to assess and respond to such situations: human resources, structural, political, and symbolic. The human resource is characterized as emphasizing people's needs and the importance of a caring and trusting environment (Deal \& Peterson, 1999). Identifying this human component among the stakeholders such as superintendents, board members, teachers, administrators and community members plays a 
major role in creating an effective learning environment. When a school district embarks on a mission to create an effective learning environment, the superintendent, working with all the stakeholders, must be the change agent within the system. Many challenges need to be addressed from within and from without our school system. It is paramount that the superintendent establishes relationships that will foster a sense of trust and cooperation among all of the stakeholders.

The superintendent plays an integral role in school improvement and the development of effective schools. What are effective schools? Are these schools only located in affluent neighborhoods in which parents are able to support schools financially and with their presence in the schools? Ron Edmonds formally identified the Correlates of Effective Schools in 1982. He believed that effective schools (no matter the location or the neighborhood) possess the following characteristics: (a) strong leadership by the principal in the quality of instruction, (b) a clear sense of mission regarding the instructional focus, (c) a safe environment for teaching and learning, (d) high expectations of all students conveyed by the teachers' behaviors, (e) program evaluation based on the frequent monitoring of student achievement, and (f) positive home and school relationships. Student achievement must be a focus of the entire school, not just of principals or teachers (Edmonds, 1982).

Although there are many factors that affect a superintendent's ability to create the desired effective learning environment and there are many plans, techniques, and methodologies a superintendent might use to do so, it is helpful to focus on a framework of superintendent responsibilities that can contribute to an effective learning environment. The framework presented here, having been culled from the literature, consists of six key leadership components of the superintendent: (a) staff development administration, (b) communication of mission, 
(c) curriculum and instruction expertise, (d) collaboration with the school board, (e) consensus building ability, and (f) political bearing.

\section{Staff Development Administration.}

Some superintendents are reluctant to visit classrooms. They believe they cannot learn anything useful from classroom visits. Yet many superintendents gain valuable insight from classroom visits through data gathering, examining student work, observing teacher initiatives, and studying instructional practices. These visits can bring a superintendent to a new level of understanding (Rallis, Tedder, Lachman \& Elmore, 2006).

Promoting student learning is directly related to teacher quality. New teachers have higher preparation standards and stronger licensure requirements than teachers of old did; particularly in regard to being "highly qualified" and the accountability of the No Child Left Behind Act. Many members of the teaching staff have acquired most, if not all, the qualifications required of new teachers. Many school systems have veteran employees who have completed advanced degrees and must rely on professional development to deepen the content knowledge and obtain appropriate teaching strategies (National Staff Development Council, 2005).

Teachers cannot teach new concepts and apply new methodologies if they do not understand the concepts or they lack the knowledge of how to effectively present the concepts. "If schools are to change, teachers must change their practice in significant ways to offer more effective instruction and produce higher levels of achievement for students" (NSDC, 2005). Staff development presents an avenue for school systems to retrain the workforce. "Learning is not workshops and courses and strategic retreats. It is not school improvement plans or individual leadership development. These are inputs. Rather learning is developing the organization, day after day, within the culture" (Fullan, 2008). 
The National Staff Development Council recommends making teaching and learning a top priority within a teacher's workday. I believe professional training should be more than just a few hours at the beginning of the school year, or within selected days throughout the year. Workshop-based programs and ongoing professional development to address individual school needs should be the beginning of a new model of staff training (NSDC, 2005). When superintendents focus on instructional practices through observations and discussion, they are better able to understand the methodology of teaching (Rallis, Tedder, Lachman, \& Elmore, 2006).

Traditional teaching techniques centered on lectures and provision of data and information. As superintendents consider new approaches to improve the teaching methods of the staff, regard must be given to the learning needs of the teachers and administrators. Considerations a superintendent must make when trying to develop an effective learning environment through professional development of the staff include (a) giving staff members the opportunity to learn in an active learning environment, (b) engaging staff in problem solving, and (c) providing teachers time for practicing the new techniques.

Professional learning communities are enhanced by school culture. If the stakeholders believe professional development is valued and considered important, it will have meaning within the school (Peterson, 2002). The more positive the culture with regard to professional development, the more valued staff development will be and the greater staff involvement in professional development will be.

A negative culture can create ill feelings and impair the development of professional development initiatives. When teachers believe that they have nothing to learn and that they have already been adequately trained, the sharing of new ideas is restricted and is not encouraged 
(Peterson, 2002). "Specifying a problem of instructional practice connected to the district's overall strategy of instructional improvement to the districts overall strategy of instructional improvement is a key element" in the improvement of practice (Rallis, Tedder, Lachman, \& Elmore, 2006).

Principals are a key in leading the culture of change. For change to begin the superintendent must involve the administrators; principals must understand the school and its community to development change. Administrators need to understand curriculum and instruction before they can begin to effect change (Peterson, 2001). Principals need to be involved in the staff development process; they need to be directly involved with the teachers and district office to establish goals and monitor initiatives as they are implemented within the classroom.

\section{Communication of Mission.}

Effective learning environments begin with a clear understanding of the priorities of the school system. Competing demands, emerging research on instructional strategies, and state and federal initiatives besiege the principals and teachers. A clear mission, together with a plan designed for change, will enable teachers and administrators to focus. As superintendents establish educational initiatives within the county school system, great care must be given to the path chosen. The plan must be understood as the superintendent, the principals, and the teachers set out together to improve schools through change (Johnson, 1996). Bennis and Nanus (1985) said "with a vision, the leader provides the all-important bridge from the present to the future of the organization."

The superintendent's mission must establish priorities that clearly define a path that leads a county school system where it should be within the next few years. This mission is not 
established as a standalone goal only reviewed every five years, but as goals that are reviewed at least yearly with checks and alterations or adjustment of course as the need occurs. The vision of a superintendent should create schools that help children become successful and, given the educational tools, to succeed globally (AASA, 1993).

An expectation of school boards is for the superintendent to effectively communicate with the stakeholders of the community (Bjork \& Kowalski, 2005). As I work with the administrators, it is difficult for me to stand in front of them to discuss directions the school system should consider without their buy-in. Superintendents must encourage principals to be instructional leaders and must provide to the staff professional development necessary to create these effective leaders. Superintendents must be willing to demonstrate this leadership, allowing principals autonomy, authority, responsibility, and central office and board support (Herman \& Stephens, 1989).

Principals can impact curriculum in ways that the superintendent cannot. The daily interaction between teachers, students, and principals through staff development, delivery of the curriculum and evaluation impacts a child's learning atmosphere (Herman \& Stephens, 1989). How can the superintendent have a direct role in developing an effective learning environment? Superintendents can impact the classroom for children by supporting teachers and principals. When the superintendent develops the mission of the county with teachers, principals, and the board of education, s/he assumes the responsibility to provide resources within the classroom and to support of the principals to make sound educational decisions, thereby promoting successful instructional leadership (Herman \& Stephens).

If the superintendent truly understands the school system and focuses resources on helping teachers and administrators be the best they can be and encouraging them to do all they 
can do, the successes realized are direct educational benefits within the classroom.

Superintendents must decide how to exercise this authority to make the system work for children (Johnson, 1996).

\section{Curriculum and Instruction Expertise.}

As superintendent, almost every decision I make impacts children. These decisions directly impact the classroom or indirectly affect the educational process for children. Even though superintendents do not teach within each classroom any longer, they can do things at the district level to affect the learning process within the classroom.

Superintendents should communicate and demonstrate to the system educational personnel the availability of the central office to serve schools; schools can use the additional expertise of skilled central office administrators and curriculum specialists. Some teachers feel that if county office personnel observed classes more frequently, the office personnel could have a greater influence on classroom practices. Some teachers also think that county employees have more credibility when offering advice or providing training if the county employees first spend time in the classroom, because then they better understood the rigors of teaching. An administrator's title does not gain respect unless teachers are confident with administrators' knowledge of the classroom (Johnson, 1996). To affect the learning process in the classroom, central office employees need to be viewed by teachers as true experts/authorities based on their knowledge, skills, and experience.

Improving instruction within the classroom means changing what teachers do in their classroom. Because most reform efforts are initiatives established though county or state departments' officials, teachers can feel as though they are not included in creating or designing 
the changes, that they merely implement changes mandated from above (Doyle \& Hartle, 1985). Such feelings can create barriers to change.

Strategic planning is crucial to enhancing learning and teaching in an educational organization. Anticipating future trends is crucial to superintendents who want to stay current with the latest research on educational reform. Synthesizing information contributes to the superintendent's decision-making process. Establishing priorities within the strategic planning process empowers individuals and groups to participate in the goals of the organization. Once the priorities are established, the educational community must be involved to plan and organize the work. This type of strategic planning process enables superintendents to frame and solve problems in decision-making (AASA, 1993).

How does a superintendent improve curriculum and instruction? Establishing priorities, implementing performance measurements, and monitoring formative and summative assessments results can provide insight into student learning. A process of systemic review must be done annually, reviewing curriculum alignment and student performance (AASA, 1993). Superintendents must assess alternative methods to evaluate student achievement.

Planning is an effective method to assess the needs of the county school system and its teachers who implement the initiative. If teachers are not consulted or their opinions are not valued, the change becomes more difficult to implement. Change is difficult because teachers and administrators are asked to alter attitudes and practices. Presently district office personnel are not considered collaborators. The thought that district office employees are a part of the change process and that they may be experts in the process is something that doesn't usually materialize and has not always been well received (Johnson, 1996). 
Effective superintendents must be willing to make regular visits to classrooms so they can determine teachers' understanding of local initiatives and observe how instructional initiatives are being implemented. Superintendents gain respect from educational personnel when teachers realize a superintendent (a) is willing to learn, (b) will offer worthwhile insights about their teaching, and (c) can identify the needs of the teacher to help the teacher better meet the needs of the student (Johnson, 1996).

The superintendent can use positional authority as a starting point for leadership; however, the superintendent can be a more effective leader if supported by other educational groups. No longer is the superintendent the only person with the educational authority to directly develop an effective learning environment. Educational leaders within the schools and community can be influential in the change process. Collaboration can emerge when superintendents encourage principals, teachers, and district personnel to assume responsibility for change (Johnson, 1996).

\section{Collaboration with School Board.}

For nearly two decades it has been thought that school quality affected a child's performance less than socioeconomic status. However, school structure and organization does affect a child's learning. School quality can be influenced by policy (Doyle \& Hartle, 1985).

Early boards of education considered their role as administrative; this limited the role of the superintendent. As boards worked with the superintendents and as confidence and responsibility developed between the board and superintendent a more extensive superintendent role developed (Griffiths, 1966).

Although organizational politics have always created conflict between boards and superintendents, the relationship of superintendent and board of education has evolved 
throughout the years. The role of the superintendent in early $19^{\text {th }}$ century was to select textbooks and to appoint and hire teachers. As social issues surged before WW I, leaders of school systems began to relate to business by trying to become more efficient. Today the demands of the superintendent require him/her to have a broader repertoire of political skills, to be involved in the community in policy matters, and to be a good communicator to effectively tell the school story (Cuban, 1985).

The superintendent's role in developing an effective learning environment evolved in three roles; (a) politician; (b) manager, who maintains organizational stability through a variety of processes_-from planning program development to evaluating program implementation; and (c) teacher, who informs newly elected school board members and helps the community understand the budget and district priorities (Cuban, 1985).

In the role of politician, the superintendent builds consensus to define district goals and make policy. At one time school districts functioned as independent bodies even though their interests were tied to city or county government. Currently business organizations, community organizations and religious groups all play an active role within the school district (Johnson, 1996). "Leadership is a political activity of corralling competing factions with conflicting definitions of the problem, getting a coherent definition of the problem that takes into account more, rather than fewer, points of view" (Bolman \& Deal, 1994).

Managers and leaders are different: "Managers are people who do things right and leaders are people who do the right thing” (Bennis \& Nanus, 1985). Abraham Zaleznik (1992) made a similar analogy: "where managers act to limit choices, leaders develop fresh approaches to long-standing problems and open issues to new options." A superintendent cannot rely solely on his/her managerial ability to produce good teaching and learning within the classroom. S/he 
does not often have the occasion to exercise and control practices in the classroom. A superintendent can direct the type of professional development within the school system, but s/he cannot directly monitor or implement these educational initiatives within the classroom. District office direction is not always met with the favorable response of teachers and principals complying with each directive. Superintendents must rely on school personnel and their initiative to comply with district guidelines and directives. Due to varied learning styles and diverse levels of community involvement, it can be difficult for a superintendent to apply appropriate practices for all teachers and principals. "Everyone from the superintendent to the teacher has to lead by managing and manage by leading" (Johnson, 1996).

The superintendent as a teacher is not a new role. The current trend for supervisor as teacher focuses on curriculum, instruction and assessment (Cuban, 1985). School boards give authority to superintendents to provide educational services to the students and teachers within the district. The superintendent allocates staff and presents educational opportunities to teachers to foster a creative learning environment. With these things in place, it becomes the responsibility of the building administrator to supervise teaching and learning (Johnson, 1996).

I have found that in my role as superintendent I should understand the governance of the board of education. A working relationship between board members and the superintendent is critical. Mutual goals and initiatives must be established to develop guidelines and implementation strategies for the school system. Monetary allocation, staff assignments and program implementation are a part of the direction set by the superintendent and school board. Change must be monitored and problem-solving strategies must be implemented if program initiatives are not successful. Assessment of initiatives permits the superintendent to monitor the educational program. 


\section{Consensus-Building Ability.}

A superintendent's ability to build consensus correlates to improved performance by all staff members. Effective staff evaluation policy and procedures are critical for adult motivation. The superintendent is better able to assess the implementation of staff development initiatives and curriculum innovations by effectively evaluating staff (AASA, 1993). Any superintendent wishing to develop an effective learning environment must be able to build consensus among the stakeholders within the educational community.

Superintendents must be skilled collaborators who look for assistance within the educational and business community. "Schools depend on the effectiveness of school superintendents" (AASA, 1993). Leadership of school districts is no longer top-down. Shared decision making among teachers, administrators, service employees, community members, and businesses is crucial for a successful school system. Leadership must be effective at all levels, including in the classrooms. Superintendents must "lead through teaching" (Cunningham, 1985). The thought that directives starting at the top will bring change is a myth. A top-down leadership does not generate creativity and cooperative initiative in others. In order for change to take place, leaders must be created within the entire system (Ogawa \& Bossert, 1995). Bennis and Nanus (1985) said, "Leading involves getting everyone to pursue a shared mission." Superintendents simply cannot rely solely on making good decisions to promote leadership that will create effective learning environments (Cohen, 1990). Superintendents must enlist the support of teachers, community leader's parents and administrators. Collaboration will encourage teachers to try educational initiatives that are supported by all of the schools stakeholders (Johnson, 1996). Leaders who rely on formal authority as a lever of change within organizations that have become extremely complex have a difficult time understanding everything that is happening 
within the organization. The thought that each community school, teacher, administrative and all activities within the classroom will be directly influenced by the superintendent presents difficulties without the support of the educational team (Crowson \& Morris, 1991).

The success of the learning environment is related to the effectiveness of the principal. The principal's ability to build professional learning communities is more effective than educators working in isolation. "Principals do make a difference in school improvement and student achievement...They are second only to the teacher" (Fullan, 2008).

Each stakeholder in the educational system is interdependent on one another to do a good job creating influence over one another (Johnson, 1996). "There is no way that one can perform well in a leadership job today without a deep understanding of the diverse and interdependent milieu surrounding the job. This means knowing who all the relevant parties are, even though there may be thousands of them" (Kotter, 1985). He further explained that leadership is reciprocal where each stakeholder must collaborate to improve education. Leadership must run in several directions to create advantages to influence others. Position is important but not the only thing (Kotter).

School reform is arduous. A few schools have been successful with school reform, but many more find it difficult to effect change. A strong superintendent can support change by examining the districts needs, proposing solutions, and supporting and inspiring teachers and principals who are committed to implementing change to improve school (Johnson, 1996).

\section{Political Bearing.}

Lasswell (1958) stated that "The study of politics is the study of influence and the influential". Superintendents working directly with school boards, teachers, administrators and communities, to provide the best possible educational environment for students, learn to 
understand this influence as they work with many different groups that have a specific interest in education. The thought of a superintendent playing politics or serving in an "educational statesman" as Callahan (1967) put it—can easily enter into the discussion of influences that a superintendent must consider as decisions are made. Many believe that stakeholders can influence individuals or groups to achieve a positive outcome within the decision-making process (Johnson, 2003). This “politics of interest” described by Petracca (1992) must be recognized by superintendents as they work in the educational community and balance the decisions made to resolve conflicts or to accomplish a workable consensus.

As educational initiatives continue to address the needs of the learner, and as funding issues continue to make it more difficult to meet the needs of the school reform, superintendents will prioritize the needs of the school community. Many of the stakeholders, such as school board members, teachers, parents, and community members, will demand to be a part of the decision-making process (Bjork, Kowalski, \& Young, 2005). Superintendents need to learn how to negotiate with those stakeholders are and carefully consider the correct timing to advance an initiative. This potential for a conflict-ridden arena pitting different groups against one another to gain superintendent support to meet the needs of their constituency is referred to as a political process of "who gets, what, where, when and how" (Laswell, 1958).

Effectively managing the leadership role to bring all groups to the table to build consensus and agreement is difficult. This is not a skill that is addressed in formal schooling but is embedded in a superintendent's routine negotiating of the demands of different groups within the community to meet the needs of students and the school reform demands. Bjork (2005) identified this practice as the" art of the possible". With the potential of conflicts among these groups due to limited funding, the instructional leader should effectively use this power of 
resolving conflicts for the greater good of the educational community. This political leadership is recognized by superintendents as they consider the political stakes of school reform, particularly when they distribute the resources among several groups from diverse backgrounds (Cuban, 1988).

Many times board members struggle under political pressure. Conflict may develop between the superintendent and a board member when one wants to advance an individual agenda. The political pressure felt by a member of the board could be from a union or from a particular issue that encouraged them to seek office. Frustration may become evident if change does not happen fast enough or if laws cannot be manipulated to serve the needs of one board member. Local governance should be a self-correcting political process focused on servicing the children of the school system (Stover, 2009).

It is not always obvious when a school board member or superintendent is motivated for political reasons. The personal dynamics between individual board members and the superintendent during a time when one is advancing their own agenda may appear to be argumentative or disruptive. An issue that normally would be considered noncontroversial may become problematic if the issue becomes a bargaining chip with one facet of the community as a board member advances his/her own cause.

To reduce the undue influence from any one group, it is imperative that school board members and superintendents police themselves and lead by example. The school environment should nurture integrity by establishing and following a set of guidelines and values of integrity (Wickersham, 2009). To achieve change or the implementation of new initiatives, superintendents must identify and challenge the needs of those political individuals or groups by 
understanding their beliefs and values about education and considering how to address those needs to create an atmosphere of cooperation (Trimble, 1996).

Superintendents need to be held accountable and should be able to meet specific competencies regarding job performance. These general professional standards are:

(a) leadership and district culture, (b) policy and governance, (c) communication and community relations, (d) organizational management, (e) curriculum planning and development, (f) instructional management, (g) human resources and management, and (h) values and ethics of leadership (AASA, 1993).

According to Johnson (1966), superintendents were effective when they demonstrated three types of leadership. These styles of leadership are:

1. An educational leadership style in which the superintendent uses his/her experience to diagnose the problems and uses his/her knowledge to consider possibilities and strategies for improvement within the system.

2. A political leadership style in which the superintendent involves him/herself within the community by interacting with city officials, school partnerships, and community leaders to secure funding and enlist public support to improve schools.

3. A managerial leadership style in which the superintendent implements district policy and organizations to encourage and influence school leaders to promote best practices and educational change.

"Leadership is the exercise of influence" (Cunningham, 1985). Superintendents need to understand and demonstrate the ethics and moral leadership to meet the needs of the students (AASA, 1993). Superintendents must have a positive attitude toward children and the needs of 
the community (Cunningham). They must be willing to demonstrate the positives aspects of change and the potential of growth from change.

Can leaders be cultivated and trained? According to Cunningham (1985), there are several steps that leaders can practice to be more effective: (a) Focus on the present and future simultaneously; (b) Build relationships with community organizations through daily communication and interaction with the stakeholders of the community, such as teachers and parents; (c) Review events, seeking clarity of information and drawing interpretations; and (d) Reassess performance, critically monitoring effectiveness of job satisfaction.

The leader is a teacher who balances political concerns and creates a management style that encourages participation by all stakeholders. The leader must know the mission and goals of the organization and constantly teach them to the members of the organization. An indication of a successful leader is when each teacher or administrator embraces the organization's goals and implements those goals within their own workspaces (Cunningham, 1985). If our primary purpose is to educate children in the most effective learning environment, then truly the role of the superintendent must be one of a teacher who listens to principals and teachers who deal directly with the students in the classroom.

\section{Summary}

How might a superintendent play a significant role in developing an effective learning environment? It appears from the research that the superintendent must rely on the stakeholders within the school building to effectively impact the education within the classroom.

Superintendents cannot create an effective learning environment alone or develop one model that works well in all contexts. According to the McREL report by Tim Waters and Robert Marzano (as cited in The School Administrator, 2007): 
1. Leadership at the district level does matter.

2. Creating teaching and learning goals as a district with administrative involvement will impact student achievement.

3. Student achievement correlates to the length of tenure of the superintendent.

Student achievement is also affected by the demonstrated leadership of the superintendent in these areas of responsibilities: (a) goal setting, (b) student achievement goals that are non-negotiable, (c) board support of established goals, (d) a process to monitor the goals, and (e) demonstrated support of goals through funding resources (Waters, \& Marzano 2007).

When the superintendent establishes a relationship with the administrators in the schools, leadership autonomy is encouraged among the principals. As the superintendent encourages the administrators to assume this leadership responsibility, s/he is also encouraging the principal to embrace the established goals of the board and superintendent (Waters, \& Marzano, 2007).

I believe education is not a standalone activity where what is spoken on high (the district office) is perceived by the schools as the best solution for given problems. District office communication is not always received with the intent it was given. Effective classrooms are designed through school board cooperation with a superintendent who listens to the administrators, teachers, students, parents and community members. Staff development is designed by and for teachers in conjunction with the superintendent who understands curriculum and instruction to maximize the performance of the schools and meet the needs of the children. A clear mission is also established by the superintendent demonstrating a leadership style that builds consensus among all of the stakeholders who believe in this vision, which sets forth the goals to accomplish an effective learning environment. 
The literature review examined the role of the superintendent in creating an effective learning environment historically as a teacher and instructional leader. In early days of the role, superintendents supervised and hired teachers; they taught within the classroom, purchased supplies and were assigned students that needed supervision and instruction. The superintendent role developed and changed over the last 150 years to one of an instructional leader who dealt with curriculum and instruction. The curriculum and instruction focus diminished as the role of the superintendent became more political and was tied to the local school boards. The emergence of the superintendent role, which deals with legal and social issues removed superintendents from working directly with students and teaches within the classroom and placed superintendents in an administrative position (CEO).

As the literature indicated, this superintendent role of instructional leader with knowledge of curriculum and teaching changed as school reformers wanted the school system to be managed as a corporation. The literature also indicated that today some school systems hire superintendents directly from the corporate world who do not have an understanding of curriculum because they have never been in a classroom nor have they been trained in teaching theory and practice. They lack the skill set and understanding of what transpires between a teacher and a classroom of students or of the role of a principal as s/he manages an instructional staff and student body. These superintendent CEO's, as the literature indicated, are more concerned about production and accountability.

As the superintendent role evolved to one of responsibility and authority, superintendents became accountable to the community and school board for issues related to recession and population declines. The superintendent — as chief executive working with the new stakeholders, taxpayers and business executives, who were elected to school boards-began making decisions 
on how best to run education. The school board, who controls the superintendent's contract, could manipulate this ability to control, by effectively facilitating policy and budgets, which may be detrimental to the better interest of the school system. Relationships between the superintendent and school board members as the literature indicated should build consensus to define policy and county goals.

Developing a leadership style that works with school board members, teachers, principals and knowing how to balance the political influence of community members is crucial for a successful school system. Involving these stakeholders from the beginning to present new initiatives in the classroom should be a role for the superintendent to create an effective leaning environment. This shared mission in the literature must be communicated from the bottom up and leadership must be at all levels including in the classrooms. Do superintendents build this consensus? Are their leadership styles promoting a mission and establishing priorities as seen only by the superintendent, or are they encouraging stakeholders to be a part of this process to establish priorities and direction for the school system?

This study explores current perspectives regarding the role of the superintendent. With respect to some current superintendent responsibilities and best practices, how do superintendents view their own effectiveness while serving in the role? What views do teachers and principals hold regarding the effectiveness of superintendents in the role as it now stands? In the eyes of teachers and principals, are superintendents "losing touch" with what is transpiring in the classroom? Is the duty of the superintendent merely to manage; does duty now remove the superintendent from the role of instructional leader?

As the literature bears out, the role of the superintendent has changed drastically since its inception. Today's superintendent is challenged with serving in a variety of important roles. 
Figure 2 provides an overview of a six-component leadership framework for superintendents that has been synthesized from the literature and serves as the basis for a measurement of superintendent efficacy in this study. 


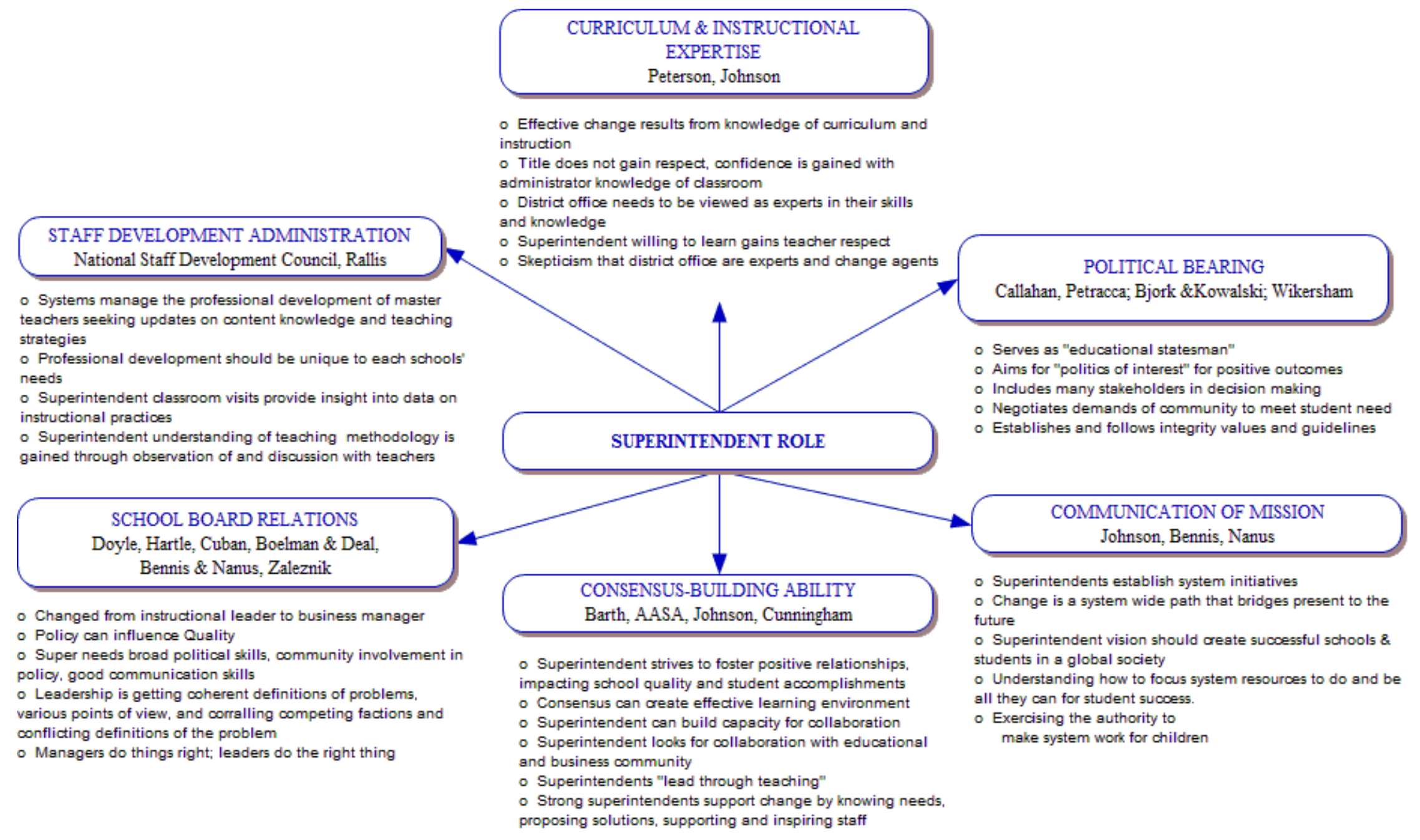

Figure 2. Superintendent six-component leadership framework. 


\section{Chapter 3 - Methodology}

Overview

This research explored the perceptions of superintendents, teachers, and administrators regarding the overall efficacy of school superintendents. This chapter begins with the Statement of the Problem. Specific research questions and hypotheses are then enumerated. The chapter then describes the survey instrument utilized for data collection - the process used to develop the instrument and the sections of the instrument. The study's population and sample are specified, followed by a discussion of analysis of data, a listing of limitations of the study, and a conclusion.

\section{Statement of the Problem}

Although a variety of criteria exist for assessing leadership quality of K-12 school superintendents, any assessment eventually utilized needs to take into consideration the various perspectives that impact overall perceptions of superintendents' efficacy: (a) superintendents' perceptions of their own efficacy, (b) principals' perceptions of their superintendent's efficacy, and (c) teachers' perceptions of their superintendents' efficacy. Although school board members' and community members' perspectives are also important, they are beyond the scope of this study. This study recognizes their importance, but will leave these issues to be addressed in subsequent studies.

The literature offers various theoretical qualities regarding what constitutes leadership efficacy among superintendents. However, as we transition from theory to evidence-based practice, what strengths and limitations become apparent when crafting real-world actual assessment tools based on these qualities? In other words, leadership theory remains esoterically useless unless we use it to actually assess superintendents' leadership qualities. This study aimed 
to illuminate the strengths and limitations of leadership theory by examining the strengths and limitations of an instrument designed around that theory.

One of the major issues that helps address these strengths and limitations is the consistency among superintendents', principals', and teachers' perceptions of those qualities. In other words, an ideal measure (i.e. instrument) of these theoretical qualities would yield similar perceptions of a particular superintendent regardless of whether one is a superintendent, a principal, or teacher.

\section{Research Questions and Hypotheses}

The study addressed two main research questions:

Research Question \#1 (RQ1): How do superintendents,' principals', and teachers' perceptions differ with respect to the relative importance of multiple roles required of effective superintendents? The null hypothesis $\left(\mathrm{H}_{\mathrm{o}}\right)$ and alternative hypothesis $\left(\mathrm{H}_{\mathrm{a}}\right)$ for RQ1 are as follows:

$\mathrm{H}_{\mathrm{o}}$ : There is no statistically significant difference in how superintendents, principals, and teachers perceive the relative importance of the components that comprise leadership efficacy among superintendents.

$\mathrm{H}_{\mathrm{a}}$ : There is a statistically significant difference in how superintendents, principals, and teachers perceive the relative importance of the components that comprise leadership efficacy among superintendents.

Research Question \#2 (RQ2): Is there a statistically significant difference when comparing teachers' perceptions of their superintendent with the perceptions of their respective supervising principal? Following are the $\mathrm{H}_{\mathrm{o}}$ and $\mathrm{H}_{\mathrm{a}}$ for RQ2: 
$\mathrm{H}_{\mathrm{o}}$ : There is no statistically significant difference when comparing teachers' perceptions of their superintendent with the perceptions of their respective supervising principal.

$\mathrm{H}_{\mathrm{a}}$ : There is a statistically significant difference when comparing teachers' perceptions of their superintendent with the perceptions of their respective supervising principal?

\section{Instrument Utilization for Data Collection}

\section{Development of the Instrument.}

As superintendent of a mid-sized school district in a rural Appalachian college town of over 100,000 residents, I frequently reflect on how detached I am from the classroom on a daily basis; and yet most of the decisions I make impact teachers, administrators and the education of the children within the classrooms of my school district. The combination of my personal knowledge of the superintendent's responsibilities along with knowledge of the set of the superintendent's historical, political, and organizational roles gleaned from the literature guided the composition and selection of questions for the Superintendent Efficacy Questionnaire (Appendix A). Dr. Sebastian R. Díaz, Dr. David Callejo Pérez and I developed the survey. Using standards synthesized from the literature review and experience as educators who have served in various educational roles, we developed a set of questions to measure superintendent efficacy.

As discussed in Chapters 1 and 2, the job of the superintendent lies within the political realm of the school board, the social realm of the community, and the pedagogical realm of teaching and learning. The role of the superintendent is complicated by the interaction of the three realms in undertakings related to curriculum mandates, community needs based on social 
and business concerns, and the issue of how to staff and pay for the basic necessities that have become expectations of the public school in America.

Review of the literature revealed that the leadership style of the superintendent should address curriculum and teaching and what needs to be done to create an effective learning environment. Dr. Díaz, Dr. Callejo Pérez and I discussed the components of the instrument, trying to determine the superintendent's perception about how s/he impacts the learning environment within the classroom. As this discussion ensued, it became apparent that we wanted to measure the leadership style in six areas, assessing how superintendents view themselves in those six areas, as well as how teachers and principals view the superintendent in those areas. It is important to gain perspective from superintendents, teachers and principals. A superintendent makes decisions based on what s/he believes is in the best interest of the school system; the views of the teachers and principals may be somewhat different from the superintendent's.

Dr. Díaz, Dr. Callejo Pérez and I collaborated in the development of this instrument via email, trying to capture the essence of what we wanted to measure, to determine how it related to the role of the superintendent regarding leadership style while realizing that a superintendent's decisions may be influenced by the school board, employees and community. Validation of the Superintendent Efficacy Questionnaire was conducted as part of this study.

\section{Sections of the Instrument.}

The Superintendent Efficacy Questionnaire is comprised of three sections. In the first section, respondents indicated their level of agreement with survey statements - strongly agree, agree, neutral, disagree, or strongly disagree-by choosing the appropriate response for each question. The six areas measured addressed the following competencies: 
1. The superintendent's ability to assess staff development needs and the impact of professional development on teaching and learning in the classroom: Within this subscale, participants responded to statements regarding their superintendent's (a) awareness of teachers', administrators' and staff development needs and (b) ability to adequately assess teachers', administrators' and staff development needs. They also indicated their level of agreement with a statement declaring that staff development results in improved teaching and learning within the classroom.

2. The superintendent's ability to plainly articulate a clear mission that establishes priorities for the county school system: This subscale asked the participant to rank his/her level of belief that

a. The district has a mission statement.

b. The superintendent clearly articulates the mission statement to school district personnel, students and the community served.

c. The mission statement sets a direction for the school system and helps to clarify priorities.

3. The superintendent's knowledge of curriculum and teaching: This subscale addressed the superintendent's demonstration of his/her knowledge of curriculum and how curriculum and teaching is practiced in the classroom, as well as whether the superintendent guides curriculum and teaching to enhance learning in the classroom. Finally, this subscale asked participants about their perception of the superintendent's impact on curriculum and teaching within the school district.

4. The superintendent's ability to work with the local school board to facilitate policy and education initiatives: This subscale questioned respondents about their opinions 
regarding the superintendent's (a) advocacy for students, teachers, administrators and staff, (b) ability to communicate effectively the concerns of the local school board to students, teachers, administrators and staff, (c) influence with the school board for establishing policies, and (d) ability to work well with the school board to carry out initiatives within the budget. In addition, this subscale sought participants' views on whether the school board values the superintendent's views.

5. The superintendent's demonstration of a leadership style that builds consensus within the schools and local community: This subscale asked the participant to rank his/her level of belief that

a. The superintendent has an effective leadership style.

b. The superintendent's leadership style builds consensus among teachers, administrators and the community.

c. The superintendent's leadership style matches well with the needs of the school district.

6. The superintendent's ability to understand the political bearing persuasion used by certain groups within the community to influence decision making. This subscale sought participants' views on the superintendent's ability to (a) negotiate effectively, (b) make things happen in the district, (c) communicate effectively, (d) use his/her power effectively with stakeholders and to resolve conflict, (e) recognize his/her constituents.

In the second section of the questionnaire, respondents rated as extremely important, somewhat important, or not at all important each of the following as they relate to contributing to a school superintendent's overall effectiveness: the superintendent's ability to (a) assess staff 
development needs, (b) choose staff development activities that impact teaching and learning in the classroom, (c) clearly articulate a well-defined mission that establishes priorities for the county school system, (d) work with the local school board to facilitate policy and education initiatives, (e) demonstrate a leadership style that builds consensus within the schools and local community, (f) demonstrate a knowledge of curriculum and teaching to enhance teaching and learning and (g) work with the school board within the budget. This section also asked participants to rate the importance of the superintendent's knowledge of curriculum and teaching as it relates to enhancing teaching and learning.

The third area of measurement in the questionnaire asked participants to rank on a scale from 1 to 5, with 1 being the most important and 5 being the least important, the relative importance of each of the following items as they relate to a superintendent's effectiveness:

1. The superintendent is able to assess staff development needs and its impact on teaching and learning in the classroom.

2. The superintendent effectively articulates a well-defined mission that establishes priorities for the county school system.

3. The superintendent's knowledge of curriculum and teaching enhances teaching and learning.

4. The superintendent's ability to work with the local school board facilitates policy and education initiatives.

5. The superintendent's demonstration of a leadership style builds consensus within the schools and local community. 
Three additional identifying questions determined the respondent's role in the school system (superintendent, principal, or teacher), sex, and degree level (bachelor's, master's, or doctoral).

\section{Population and Sample}

The population for the study encompassed all superintendents, principals and teachers in K-12 public school districts within the United States. The sample for the study consisted of superintendents, teachers and principals from the state of West Virginia. Fifty-four of the 55 superintendents representing the county public school districts in the state were asked to participate in this survey study that measures participants' perception of superintendent efficacy.

At the time of the study, 360 teachers in the state of West Virginia had achieved National Board Certification. A request was made to the certification department of the West Virginia State Board of Education for the then-current active list of practicing teachers in West Virginia who had achieved National Certification from National Board for Professional Teaching Standards (NBPTS). This group of teachers was selected because of the rigors to attain National Board and to determine their perception of staff development to effect change within the classroom. "National Board Certified Teachers raise student achievement and are committed to improving their schools" (Aguerrebere, 2008). Email addresses and school mailing addresses for all teachers on the list were requested as well.

The third group of participants who were asked to participate in this study consisted of principals, approximately 700 serving the children in West Virginia public schools at the elementary, middle, and high school levels. The survey assessed principals' views on their superintendents' ability to effect change within the school and classroom. 


\section{Data Collection}

Each potential participant was assigned a pseudo-random identifier number to help ensure anonymity and an email was sent to all individuals requesting participation in the study. Teacher participants were asked to complete an online survey using SurveyMonkey (SurveyMonkey.com, 1999) that assessed their views of superintendent efficacy. One month after the initial request for teacher participation, a second request was emailed to those not responding to the initial request. Nationally certified teachers in this local county were not asked to participate in this study.

A request to the Executive Director of the West Virginia Association of School Administrators (WVASA) was made to identify the superintendent population in the state and provide a list of superintendents and their email and school mailing addresses. Each superintendent was asked by email to submit survey responses anonymously via the Internet. Any superintendent who had not responded within a month was sent a second request by email to participate in the study. Each survey had a code affixed that Dr. Diaz maintained. To protect the anonymity of each participant, all survey responses were delivered to Dr. Diaz. The local county school district was excluded from the study because I serve as Superintendent of Schools in that county.

A list of approximately 700 principals was requested from the West Virginia Department of Education. Each principal was asked through email to participate by completing the online survey. Each principal was assigned a number, which designated his/her programmatic assignment: high school, middle school, or elementary school. Two hundred forty-five principals responded to the survey. Local principals in the researcher's own school district did not participate in this study. 
Dr. Diaz assisted with sending out email to teachers and principals to protect their anonymity. I believed that teachers and principals would be reluctant to respond to the survey if they believed their anonymity would be compromised. Since I know professionally all of the superintendents within the state, the invitation to take the survey carefully explained to respondents how their anonymity was to be assured through the online survey.

Superintendents had the largest response rate, 79.6\%. Nationally Certified Teachers' response rate, $35 \%$, was quite similar to that of principals, $34.8 \%$. The majority $(66 \%)$ of the respondents were female.

\section{Analysis of Data}

The Statistical Package for Social Sciences was used for data analyses. Descriptive statistics were used to describe the sample's demographics. Descriptive analyses for the study made use of participants' (a) programmatic level—elementary, middle, high, district (implicit for superintendent role); (b) sex_female, male; and (c) education level—bachelor's, master's, doctoral.

Research Question 1 was analyzed using the Kruskal-Wallis nonparametric test to compare rankings. This test is the nonparametric corollary to the more conventionally used Analysis of Variance, which is dependent upon the assumptions that all the populations being compared are normally distributed and that the population variances are equal. The KruskalWallis nonparametric test does not restrict the populations under comparison to those that have normal distributions and equal variances (Bluman, 2007). The independent variable, role, had three levels: superintendent, principal and teacher. The dependent variable was the participants' scores on the Superintendent Efficacy Questionnaire. The level of significance was set a priori at the conventional $\alpha=0.05$ that is often used in social sciences research. The test determined 
whether there exists a significant difference in how superintendents, teachers, and principals perceive the relative importance of the components that comprise leadership efficacy among superintendents.

Research Question 2 was analyzed using a related samples $t$ test to compare teachers' and principals' perceptions of their superintendents. The dependent variable was the participants' scores on the Superintendent Efficacy Questionnaire; the independent variable was role, with two levels - teacher and principal. Since multiple teachers corresponded to each principal, the mean average of teachers' ratings for their respective superintendent was used as a single score.

To ensure anonymity of responses a random group identifier was assigned to each county: A-Z was used then AA, BB, CC, DD. The data was then sorted by county and ordered the information by number sequenced by school to determine those teachers and principals responding were from the same school assignment. All the superintendents' responses were removed. A total of 23 principal to teacher match in the same school location were found. The null hypothesis was tested at the 0.05 level of significance.

\section{Limitations}

The study had limitations that should be considered before generalizing the results:

1. The instrument had not been validated prior to this study.

2. The instrument is a self-report instrument. Confounding factors might have influenced participants' perceptions. For example, a principal's perception of his/her superintendent might have been confounded by a recent interaction with the superintendent or by the principal's general like or dislike for the superintendent.

3. The teachers employed in this study are National Board Certified, and therefore may not represent all teachers in the population. 
4. Leadership is a complex construct, and this instrument does not pretend to capture all the elements and nuances that comprise leadership.

5. Principals and Nationally Certified teachers employed by the local Board of Education were not selected as a part of this study. They may not have been totally open to express their opinions concerning several of the statements listed within the questionnaire, since I serve as superintendent of the local school district.

\section{Conclusion}

This dissertation research study explored school superintendent efficacy through the perceptions of superintendents, teachers, and principals. Implementing survey research methods, the study addressed two main research questions that focused on whether differences exist in the three group's perception of the relative importance of six superintendent leadership components and on whether there are differences in how teachers and their respective principals perceive their superintendents' overall efficacy with respect to the leadership components. The sample for the study consisted of superintendents, principals and nationally board certified teacher from across the state of West Virginia. Limitations of the study include use of an instrument that had not been validated, and the fact that self-reporting is subject to influence by confounding factors. The research aimed to illuminate the strengths and limitations of leadership theory by examining the strengths and limitations of the survey instrument that was developed around that theory. 


\section{Chapter 4 - Results}

The purpose of this study was to examine the superintendent's efficacy in developing an effective learning environment, in particular, through examining superintendents', principals' and teachers' perceptions of a theory-based framework of superintendent leadership components. The study yields a newly developed instrument, Superintendent Efficacy Questionnaire, to measure perceptions with respect to that leadership components framework. The data gathered by this survey instrument may inform what superintendent leadership components are perceived as important by teacher and principals; it will help educators understand the superintendent's ability to effect change in the classroom through staff development administration, articulating a mission, working with the school board, demonstrating knowledge of curriculum and teaching, and through concentrated efforts (such as consensus building) in working with the principals and teachers to bring about change.

The findings of the study will potentially assist acting superintendents with decisionmaking regarding what should be considered as they direct instruction to create an effective learning environment.

These two main research questions comprised the basis for this exploration of the superintendent's role in developing effective learning environments:

1. How do superintendents,' principals', and teachers' perceptions differ with respect to the relative importance of multiple roles required of effective superintendents?

2. Is there a statistically significant difference when comparing teachers' perceptions of their superintendent with the perceptions of their respective supervising principal? 
This study contributed a tool that can potentially clarify some strengths and limitations of leadership theory, thereby helping to connect theory and practice of leadership principles in K-12 schools.

\section{Relative Importance of Leadership Components}

RQ1: How do superintendents, 'principals', and 'teachers' perceptions differ with respect to the relative importance of multiple roles required of effective superintendents? Participants were asked to rate the relative importance of seven factors related to the overall effectiveness of a school superintendent: (a) ability to make staff development choices that impact teaching and learning in the classroom, (b) clear articulation of a mission/vision that establishes priorities for the school district, (c) ability to work with the school board to facilitate policy and education initiatives, (d) knowledge of curriculum and teaching that enhances teaching and learning, (e) ability to assess staff development needs, (f) demonstration of a leadership style that builds consensus within the schools and local community, and (g) ability to work with the school board within the budget.

A Kruskal-Wallis nonparametric test was conducted to compare the perceptions of West Virginian school superintendents' $(\mathrm{N}=41)$, principals' $(\mathrm{N}=211)$ and nationally certified teachers' $(\mathrm{N}=106)$ regarding the relative importance of these seven leadership components (see Kruskal-Wallis results in Table 1). The test produced statistically significant results for two of the leadership components:

1. The superintendent's ability to clearly articulate a mission and/or vision that establishes direction and priorities for the system $\left(\chi^{2}=10.99 ; d f=2 ; \mathrm{p}=0.004\right)$. As shown in Table 2, superintendents had a mean rank of 197.23, principals had a mean rank of 183.04, and teachers had a mean rank of 162.43. Therefore, we reject the null 
hypotheses that no differences exist among the three groups' perceptions of the importance of this particular characteristic. This suggests that role does play a part in perception of the relative importance of the superintendent's ability to articulate a clear mission.

2. The superintendent's ability to work with the local school board within the budget $\left(\chi^{2}=7.260 ; d f=2 ; \mathrm{p}=0.027\right)$. Table 2 shows that superintendents had a mean rank of 198.17, principals had a mean rank of 180.41 , and teachers had a mean rank of 168.79. Therefore, we reject the null hypotheses that no differences exist among the three groups' perceptions of the importance of this characteristic. This suggests that role does play a part in perception of the relative importance of the superintendent's ability to work with the school board within the budget.

It should also be noted that a third leadership component was marginally close to being statistically significant: the superintendent's ability to make staff development choices that impact teaching and learning in the classroom $\left(\chi^{2}=5.467 ; d f=2 ; \mathrm{p}=0.65\right)$.

When comparing superintendents', principals' and teachers' ratings of the importance of the superintendent leadership subscales inherent in this survey, no statistically significant difference was found for the item addressing the superintendent's ability to work with the school board on policy and education initiatives $\left(\chi^{2}=4.164 ; d f=2 ; \mathrm{p}=0.125\right)$. Therefore, with respect to the superintendent's ability to work with the school board on policy and education initiatives, we fail to reject the null hypothesis that there is no statistically significant difference based on role in perception of this leadership's relative importance. Additionally, we fail to reject the null hypothesis with respect to the following superintendent leadership subscales, as no statistically significant difference was found for comparisons of superintendents', principals' and teachers' 
ratings of the importance of these subscales (see Table 1): (a) the superintendent's knowledge of curriculum and teaching, (b) the superintendent's ability to assess staff development needs, and (c) the superintendent's demonstration of a leadership style that builds consensus within the schools and local community.

Table 1

Kruskal-Wallis Test Results

Leadership subscale

$\chi^{2} \quad d f \quad p$

Ability to impact classroom by staff development choices

$5.467 \quad 2 \quad 0.065$

Clear articulation of mission and/or vision

$10.990 \quad 2 \quad 0.004^{*}$

Ability to work with school board on policy and education initiatives

$4.164 \quad 2 \quad 0.125$

Knowledge of curriculum and teaching

$2.806 \quad 2 \quad 0.246$

Ability to assess staff development needs

$0.411 \quad 2 \quad 0.814$

Demonstration of consensus-building leadership style

$0.594 \quad 2 \quad 0.743$

Ability to work with the school board within the budget

$7.260 \quad 2 \quad 0.027^{*}$

$*_{p}<0.05$.

Table 2 details the respondent role mean rank results from the Kruskal-Wallis test. Teachers had a higher mean rank than superintendents and principals for two of the leadership subscales - those dealing with knowledge of curriculum and consensus-building leadership style. Principles had the highest mean rank for four of the seven leadership subscales; teachers had the lowest mean rank for those same four subscales. 
Table 2

Leadership Subscale Mean Rank by Respondent Role

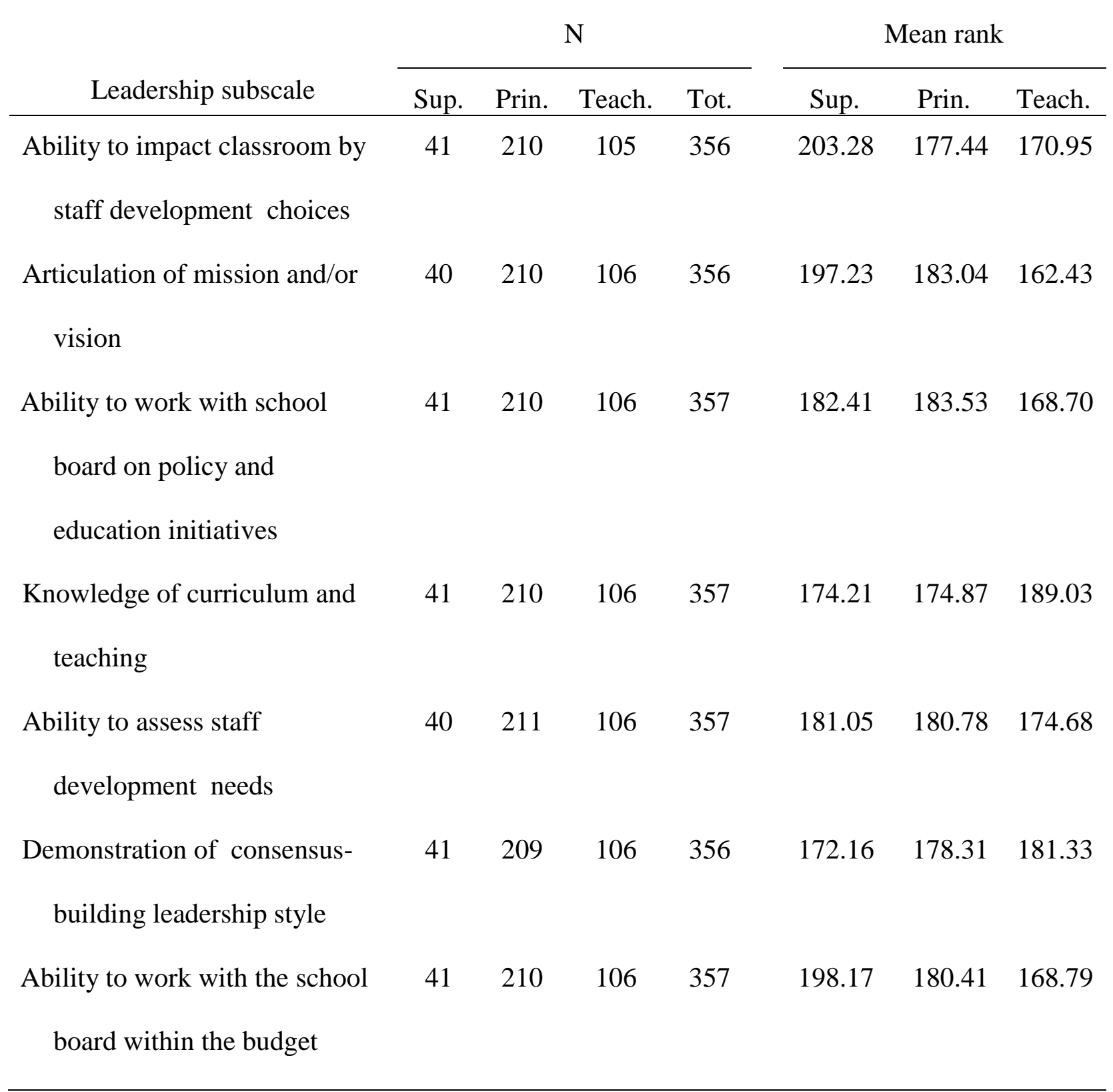

Note. Sup. $=$ Superintendent. Prin. $=$ Principal. Teach. $=$ Teacher. Tot. $=$ Total. 
To examine the relative importance of superintendent leadership skills, the issues relating to working with the school board were merged, as were the issues relating to staff professional development; and participants were asked to rank - on a scale from 1 to 5, with 1 being the most important and 5 being the least important - the relative importance of five factors related to the overall effectiveness of a school superintendent: (a) knowledge of curriculum and teaching to enhance teaching and learning, (b) clear articulation of a mission/vision that establishes priorities for the school district, (c) demonstration of a leadership style that builds consensus within the schools and local community, (d) ability to work with the school board to facilitate policy and education initiatives within the budget, and (e) ability to assess staff development needs within the system to impact teaching and learning in the classroom.

Table 3 shows each group's mean ranking in terms of relative importance of the five leadership components. It gives the perspective of each group when looking at the overall role of the superintendent. The review of the three different group's rank of the superintendent leadership components from the most important to least important role clearly indicates that none of the groups were consistent with one another. Superintendents' and teachers' rank orders were distinctly different in all five items; whereas superintendents' and principals' ranked orders had some similarities. Superintendents and principals ranked articulation of the mission as the most important leadership component (mean ranking of 2.59 and 2.35, respectively). Teachers ranked building consensus as the most important component (mean ranking of 2.53) and working with the school board as the least important (mean ranking of 3.41). Assessing staff development was the lowest ranked component by principals and superintendents (mean ranking of 3.69 and 3.76, respectively). 
Table 3

Leadership Subscale Mean Ranking by Respondent Role

\begin{tabular}{|c|c|c|c|c|c|}
\hline Leadership subscale & Role & Mean & $\mathrm{N}$ & SD & Sum \\
\hline \multirow[t]{4}{*}{ Curriculum/teaching knowledge } & Super. & 3.16 & 38 & 1.326 & 120 \\
\hline & Principal & 3.08 & 205 & 1.346 & 632 \\
\hline & Teacher & 2.64 & 98 & 1.357 & 259 \\
\hline & Total & 2.96 & 341 & 1.359 & 1011 \\
\hline \multirow[t]{4}{*}{ Clear articulation of mission/vision } & Super. & 2.59 & 37 & 1.443 & 96 \\
\hline & Principal & 2.35 & 202 & 1.462 & 474 \\
\hline & Teacher & 3.18 & 98 & 1.508 & 312 \\
\hline & Total & 2.62 & 337 & 1.515 & 882 \\
\hline \multirow[t]{4}{*}{ Consensus-building leadership style } & Super. & 2.77 & 39 & 1.385 & 108 \\
\hline & Principal & 2.56 & 204 & 1.336 & 523 \\
\hline & Teacher & 2.53 & 99 & 1.417 & 250 \\
\hline & Total & 2.58 & 342 & 1.363 & 881 \\
\hline \multirow[t]{4}{*}{ Ability to work with school board } & Super. & 2.61 & 38 & 1.264 & 99 \\
\hline & Principal & 3.24 & 206 & 1.372 & 668 \\
\hline & Teacher & 3.41 & 97 & 1.305 & 331 \\
\hline & Total & 3.22 & 34 & 1.357 & 1098 \\
\hline \multirow[t]{4}{*}{ Ability to provide effective staff development } & Super. & 3.76 & 38 & 1.384 & 143 \\
\hline & Principal & 3.69 & 204 & 1.123 & 752 \\
\hline & Teacher & 3.14 & 98 & 1.284 & 308 \\
\hline & Total & 3.54 & 340 & 1.225 & 1203 \\
\hline
\end{tabular}

Note. Super. $=$ Superintendent. 


\section{Comparison of Teachers' and Principals' Perceptions of the Superintendent}

RQ2: Is there a statistically significant difference when comparing teachers' perceptions of their superintendent with the perception of their respective supervising principal?

There were six subscales in this portion of the survey. These subscales measured superintendent leadership components: (a) ability to assess staff develop needs within the district, (b) ability to articulate a mission and/or vision to establish priorities, (c) knowledge of curriculum and teaching to enhance teaching and learning, (d) ability to work with the local school board to facilitate policy and educational initiatives, (e) ability to build consensus within the schools and local community, and (f) ability to recognize his/her constituents as the superintendent negotiates and resolves conflicts. Related sample $t$ tests were conducted to examine differences between teachers' aggregate perception and their associated supervisor's perception of the leadership components.

A related $t$ test (results in Table 4) detected no significant difference in teachers' aggregate rating and their associated principal's rating of the superintendent's ability to assess staff development needs $(t=0.876, p<0.391)$. Furthermore, as Table 4 shows, no significant differences were found between teachers' and their respective principal's perspective with respect to the remaining five leadership components. 
Table 4

Paired $t$ Test Results for Teachers and Principals

\begin{tabular}{|c|c|c|c|c|}
\hline Pair & Leadership component & $t$ & $d f$ & Sig. \\
\hline \multirow[t]{2}{*}{1} & T: Ability to assess staff development needs & 0.876 & 21 & 0.391 \\
\hline & P: Ability to assess staff development needs & & & \\
\hline \multirow[t]{2}{*}{2} & $\mathrm{~T}$ : Ability to articulate a mission and/or vision & 0.442 & 20 & 0.663 \\
\hline & P: Ability to articulate a mission and/or vision & & & \\
\hline \multirow[t]{2}{*}{3} & T: Knowledge of curriculum and teaching & 1.275 & 20 & 0.217 \\
\hline & P: Knowledge of curriculum and teaching & & & \\
\hline \multirow[t]{2}{*}{4} & T: Ability to work with the local school board & 1.627 & 20 & 0.119 \\
\hline & P: Ability to work with the local school board & & & \\
\hline \multirow[t]{2}{*}{5} & T: Ability to build consensus & 0.500 & 20 & 0.622 \\
\hline & P: Ability to build consensus & & & \\
\hline \multirow[t]{3}{*}{6} & $\mathrm{~T}$ : Ability to recognize constituents in & 0.636 & 20 & 0.532 \\
\hline & negotiation/conflict resolution & & & \\
\hline & P: Ability to recognize constituents in & & & \\
\hline
\end{tabular}

Sig. $<0.05$ (2-tailed)

Note: $\mathrm{T}=$ teacher. $\mathrm{P}=$ principal.

\section{Other Findings}

Relative Importance of Leadership Components.

Participants were asked to rate the relative importance of leadership components related to a superintendent's effectiveness, with a rating of 1 indicating not at all important and a rating 
of 3 indicating extremely important. The two items related to the superintendent's ability to work with the school board received the highest ratings: working with the school board within the budget $($ mean $=2.86 ; s d=0.361)$ and working with the board to facilitate policy and initiatives (mean $=2.85 ; s d=0.379)$. The superintendent's ability to assess staff development needs received the lowest rating with a mean of 2.68 and a standard deviation of 0.489 . Appendix B summarizes the descriptive statistics for the participants' ratings of superintendent leadership components.

\section{Description of the Sample.}

The following cross tabulations inform the general make-up of respondents' group membership. They are not, however, intended to inform a-priori group comparisons.

Two-hundred and seventy-one (66\%) of the respondents were female and $142(34 \%)$ were male. The largest group of respondents was principals (59\%), followed by teachers (31\%) and Superintendents (10\%). Table 5 shows the distribution of the sample by role and gender. 
Table 5

Sample Distribution by Role and Gender

\begin{tabular}{lcccc}
\hline & \multicolumn{4}{c}{ Number of Respondents } \\
\cline { 2 - 5 } Gender & Superintendents & Principals & Teachers & Total \\
\hline Female & $15(5.54 \%)$ & $138(50.92 \%)$ & $118(43.54 \%)$ & $271(65.62 \%)$ \\
Male & $28(19.78 \%)$ & $106(76.65 \%)$ & $8(5.63 \%)$ & $142(34.38 \%)$ \\
Total & $43(10.41 \%)$ & $244(59.08 \%)$ & $126(30.51 \%)$ & $413(100.00 \%)$ \\
\hline
\end{tabular}

Superintendents had the largest response rate, 79.6\%. Nationally Certified Teachers' response rate, $35 \%$, was quite similar to that of principals, $34.8 \%$.

Table 6 shows that 389 participants (94\%) held a master's degree at the time of the study. All principals and superintendents who participated in the study held a master's or doctoral degree; most teachers who responded held a master's degree. Strictly by role, principals $(\mathrm{N}=$ 245 or $59 \%$ ) comprised the largest group of respondents.

Table 6

Sample Distribution by Role and Degree Held

Number of Respondents

\begin{tabular}{llll}
\cline { 2 - 4 } Degree Held & Superintendents & Principals & Teachers
\end{tabular}

\begin{tabular}{lcrcc}
\hline Bachelor's degree & $0(0 \%)$ & $0(0 \%)$ & $8(100 \%)$ & $8(2 \%)$ \\
Master's degree & $35(9 \%)$ & $240(62 \%)$ & $114(29 \%)$ & $389(94 \%)$ \\
Doctoral degree & $8(50 \%)$ & $5(31 \%)$ & $3(19 \%)$ & $16(4 \%)$ \\
Total & $43(10 \%)$ & $245(59 \%)$ & $125(30 \%)$ & $413(100 \%)$
\end{tabular}


Additional demographic information was requested to determine the programmatic areas to which teachers and principals were assigned when the survey was administered. As shown in Table 8, respondents assigned to elementary schools returned the largest percentage of surveys (57\%). Respondents assigned to the high schools returned 17\%; respondents assigned to middle schools showed the lowest return percentage (14\%). It should be noted that $12 \%$ of the respondents did not indicate their programmatic areas. Fourteen of the 44 respondents who did not indicate a present teaching assignment were Nationally Certified Teachers who indicated to the reviewer that they are no longer assigned to a classroom but are working in another capacity as county office administrators, academic coaches or within the state department.

Table 7

Sample Distribution by Role and School Type

\begin{tabular}{lcccc}
\hline \multirow{2}{*}{ School type } & \multicolumn{3}{c}{ Number of Respondents } \\
\cline { 2 - 4 } & Superintendents & Principals & Teachers & Total \\
\hline 0 & 0 & $30(68 \%)$ & $14(32 \%)$ & $44(12 \%)$ \\
High school & $1(2 \%)$ & $27(42 \%)$ & $36(56 \%)$ & $64(17 \%)$ \\
Middle school & 0 & $35(69 \%)$ & $16(31 \%)$ & $51(14 \%)$ \\
Elementary school & 0 & $154(72 \%)$ & $61(28 \%)$ & $215(57 \%)$ \\
Total & 1 & $246(66 \%)$ & $127(34 \%)$ & $374(100 \%)$ \\
\hline
\end{tabular}

\section{Instrument Reliability.}

Cronbach's alpha coefficient for internal consistency reliability was calculated for the Superintendent Efficacy scale and subscales. Calculation for overall reliability of the survey 
yielded a Cronbach alpha of 0.972 , indicating that respondents consistently responded to the survey questions. Table 8 summarizes the calculations for the subscale domains.

Table 8

Reliability Statistics for Survey Subscale Domains

Subscale domain Number of items Cronbach's $\alpha$

$\begin{array}{lll}\text { Assessment of professional development needs } & 6 & 0.931 \\ \text { Communication of mission } & 7 & 0.943 \\ \text { Curriculum \& teaching expertise } & 4 & 0.443 \\ \text { School Board collaboration } & 7 & 0.905 \\ \text { Consensus-building ability } & 5 & 0.970 \\ \text { Political bearing } & 6 & 0.951\end{array}$

\section{Narrative Results.}

Two narrative questions were presented to the respondents asking for additional comments about the survey they attributed to the efficacy of the superintendent. The first question is: Are there any other factors that were not addressed in this survey that you believe contribute to a superintendent efficacy? If so, please describe them in the area designated on the survey.

Of the 86 respondents who chose to reply to this question a number of important themes were evident from their responses: (a) communication, (b) creation of leaders, (c) intelligence, (d) experience, (e) district cultural, (f) visionary, and (g) proximity.

Communication was a strong theme mentioned by the respondents, even though this question was addressed within the descriptors of articulation of mission and vision and the superintendent works with the school board. Several respondents felt the communication 
exhibited by the superintendent should be in addition to the items mentioned in the survey. The respondents wanted the superintendent to be a "good listener, to the local education community, or s/he should be a good listener and ask questions of the principals as to needs and not to rely on central office directors, and one responder felt that communication was covered but there needs to be a strong value placed on the receptive side more so than the communication side."

The second strongest theme suggested by those responding was a desire for the superintendent to create and inspire leaders. The comments were relative to the personnel hired by the superintendent to carry out the mission of the school district. Such comments were: "'His ability to recognize who will work the best in the central office toward his goals and hiring those individuals." Another respondent wanted me to understand "the superintendent is not alone. He needs other people at the board office to be good at what they do also." One respondent indicated the superintendent inspired others by "not asking anything of his staff that he is not willing to do. He has a very clear focus of the direction he expect our county to move toward, and directs others to what his expectations of our responsibilities are to also reach these common goals"

The second question is: Please use the space below to make any additional comments regarding factors that contribute to a superintendent's efficacy or any other issues germane to this survey.

Of the 53 respondents who chose to reply to this question several major themes were evident from their responses: (a) effective leadership, (b) morale concerns, (c) ineffective leadership, (d) building relationships, and (e) negative comments.

Two strong themes emerged from these narrative responses. The first theme centers around disparaging remarks made about their present superintendent. Examples of these comments are: "I'm concerned that the superintendent is more concerned with putting a good PR 
spin on student achievement/education rather than addressing many important issues" and "Ours is a nice man with absolutely NO leadership ability".. A third commenter wanted the superintendent to leave by relating "hope that ... would soon retire."

A second theme was just the opposite and was complementary, addressing effective leadership. One respondent expressed it this way; "One factor which influences the success of our superintendent not directly mentioned in the survey would be the delegation of tasks. Assistant Superintendent of Curriculum and Instruction makes our county one of the best counties for ... staff development for all teachers." A second comment pointed out that "the superintendent needs to have foresight and be open to new innovative ideas"; another mentioned "the ability to successfully manage conflict situations." 


\section{Chapter 5 - Discussion and Implications}

The purpose of this study was to examine the superintendent's efficacy in developing an effective learning environment, in particular, through superintendents', principals' and teachers' perceptions of a theory-based framework of superintendent leadership components. The study uses a newly developed instrument, Superintendent Efficacy Questionnaire, to measure perceptions with respect to the leadership components framework. The results of the survey instrument indicated what superintendent leadership components are perceived as important by teachers and principals; it will help educators understand the superintendent's ability to effect change in the classroom through staff development administration, articulation of a mission, working with the school board, demonstrating knowledge of curriculum and teaching, and through concentrated efforts, such as consensus building, when working with principals and teachers to bring improvements in teaching and student learning.

The findings of this study will help acting superintendents - and those considering becoming superintendents-in deciding the necessary steps to pursue as they consider ways to create an effective learning environment.

Two primary research questions comprised the basis for this exploration of the superintendent's role in developing effective learning environments:

1. How do superintendents,' principals', and teachers' perceptions differ with respect to the relative importance of multiple roles required of effective superintendents?

2. Is there a statistically significant difference when comparing teachers' perceptions of their superintendent with the perceptions of their respective supervising principal? 


\section{Limitations}

One constraint of this study is exemplified by the level of concern for privacy exhibited by the participants concerning anonymity of responses if they were to participate in the study. Several participants requested the examiner of data to reiterate the level of confidentiality that would be maintained in the study. Many wanted the assurance that their responses would remain anonymous and that any identification of name or school district would not be shared with me. In spite of the examiner's assurance of confidentiality, approximately 20 participants chose to stop answering survey questions after completing only a few questions. Researchers should not have to worry about the reliability of participants' responses because the respondents are fearful of a breach of confidentiality. Educators who participate in research studies should not have to be concerned about their responses being shared and used against them if they are considering advancement within the profession. However that was the case in this study.

People choose not to participant in surveys for a myriad of reasons. This reluctance by individuals to participate needs to be addressed for future research. Participants may be hesitant to participate, fearing the information they share will be compromised and future opportunities for advancement will be affected because they shared their honest opinions about their superiors. The possibility that individuals may skew their responses because of fear of some type of retaliation is an issue of concern to researchers. Several potential participants questioned Dr. Diaz, seeking assurances of anonymity for their responses; they sought information on what would be done with their identifying information if they were to contribute to the survey. These worries expressed to Dr. Diaz about the confidentiality of their responses and the possibility that their responses could get back to their superintendent not only affect this research but also call into question many other surveys and questionnaires educators are asked to complete. This 
perceived (real) fear may cause someone not to participate or honestly state their opinions. This reluctance by participants can hinder research designed to gain accurate information which could guide decision making and assist in school improvement initiatives.

It is conceivable that at any given time, potential research participants are considering opportunities to advance to positions or schools within the school district where they are presently employed. Asking employees to complete a survey that solicits responses construed as negative may cause someone to reconsider their participation in the survey. Principals and teachers understand that superintendents will play a role in their potential career moves by recommending to the board an employee to fill the vacancy. If research participants thought their responses to a survey might be compromised or misconstrued as being uncooperative or troublesome, they may be reluctant to identify their true ideas or feelings about a particular question. This perception could impact a person's ability to be candid as s/he completes the survey or cause him/her not to participate in the research. Even though school laws protect employees from arbitrary or capricious treatment and permit teacher movement to another teaching position based on specific criteria, I believe that many potential participants for this study were concerned that if they participated in this survey their responses could be harmful to them during their careers.

Conversely, I was also extremely pleased to have had many individuals contact me to share their feelings about this research and demonstrate a desire to participate in the study. They expressed to me personally that they felt the results of the study would be important and they wanted to be a part of the results. Several of these individuals who are colleagues and friends expressed a need to share their perceptions about the role of superintendent. One caller indicated that he felt many educators within the system needed to be involved with creating an effective 
learning environment, and that if this study could present some indication on how these three groups interact in their perception of one another, it could have positive results. Another caller expressed hope that this research would express a "connectedness" between the classroom, school and district decision makers.

A second limitation is the timeframe of this study. The survey was administered during the same period as high stakes, state-level testing of student performance: two of the four weeks allotted to complete the survey were testing weeks.

The sense of urgency among teachers and principals for their students to perform well on this state test could have been a contributing factor to potential respondents' decision to not take the time to participant in the survey. Principals and teachers are directly involved with testing. The pressure educators feel to complete educational concepts before testing begins, to ensure that all students have been taught the appropriate material, creates anxiety. It is possible that the teachers and principals wanted to focus all of their time and energy on last-minute, contentspecific instruction to prepare students for the state tests and on making sure students attended on testing days - without having any outside distractions. Some principals and teachers may have considered the suggested fifteen minutes of time needed to complete the questionnaire to be too much time to sacrifice during high-stakes testing in their schools. When educators are placed in a position to choose between completing a survey and instructing students, the later will prevail.

A third limitation of the study is the frequency and volume of questionnaires in which principals, teachers and superintendents are asked to participate. A number of individuals and organizations, including state and federal agencies, requested information from the prospective participants of this study during the same time period this research project was conducted. I was asked to complete more than 10 surveys - each of 15 to 30 minutes in length - during the survey 
window of this research project. The necessary time commitment to complete so many surveys could have been a contributing factor for some of the individuals' decisions to not participate in this study.

Researchers' gleaning of the opinions of teachers, principals and superintendents can prove invaluable. However, the volume of questionnaires that are administered to these groups of educators could have been a contributing factor for some of the individuals not completing the survey. Sending an accompanying letter that explained the purpose of this survey may have contributed to some participants' decisions to take the time to respond.

Knowing all of the superintendents personally for this study may have increased the likelihood of their participation. Several specifically spoke to me expressing their wishes to complete this survey because of our collegial relationship and their desire to help. They felt the results could be representative of needs in their own school system. The willingness of superintendents to participate was demonstrated by completion of 43 of the 54 superintendents' surveys - a79.6\% return rate, which is the highest participation rate of the three groups.

An unexpected limitation occurred during the study: many meetings and webinars to discuss monetary disbursements regarding the American Reinvestment \& Recovery Act (ARRA) were scheduled for superintendents. These meetings and subsequent conferences at the district level were time consuming for superintendents. I personally attended, either physically or electronically, at least seven of these meetings.

The timeliness of questionnaires requested and the amount of work teachers and principals are facing at a given time will have a direct correlation to the number of participants who decide to complete the survey. Future researchers should consider educators' workloads during busy periods such as the beginning and the end of the school year and testing windows, as 
well as holiday breaks, before requesting participation in research projects. These less-thandesirable times, with their associated stresses on teachers and school administrators, could result in fewer participants completing the studies' activities.

\section{Discussion}

Relative importance of leadership components.

The first hypothesis concerning the perceptions of superintendents', principals', and teachers' perceptions of the relative importance of the multiple roles effective superintendents perform within the purview of their job was significant in two areas:

1. The superintendents' ability to clearly articulate a mission and/or vision that establishes direction and priorities for the system $\left(\chi^{2}=10.99 ; d f=2 ; \mathrm{p}=\right.$ $0.004)$; and

2. The superintendent's ability to work with the local school board to facilitate policy and education initiatives with the budget $\left(\chi^{2}=7.260 ; d f=2 ; \mathrm{p}=0.027\right)$.

Table 9 compares each group's relative importance ranking of the five leadership components. It shows the perspective of each group when looking at the overall role of the superintendent. The questionnaire ranked each item from one to five, with one representing the most important and five the least important.

When comparing the three different group's rankings of the importance of these leadership components, it is clear that none of the group's perceptions are consistent with one another. It is also clear that the superintendents and principals ranked articulating a clear mission as the most important component and ranked the ability to assess staff development as the least important. The other areas ranked similarly by superintendents and principals were knowledge of curriculum and building consensus: these two items were one order ranking away from each 
other. In comparison, working with the local school board regarding policy and budget had a spread of two rankings.

Table 9

Leadership Components' Relative Importance Ranking by Respondent Role Ranking

Leadership Component Superintendents Principals Teachers

\begin{tabular}{lccc}
\hline Assess staff development & $5^{\text {th }}(3.76)$ & $5^{\text {th }}(3.69)$ & $3^{\text {rd }}(3.14)$ \\
Articulate mission & $1^{\text {st }}(2.59)$ & $1^{\text {st }}(2.35)$ & $4^{\text {th }}(3.18)$ \\
Display curriculum knowledge & $4^{\text {th }}(3.16)$ & $3^{\text {rd }}(3.08)$ & $2^{\text {nd }}(2.64)$ \\
Work with school board & $2^{\text {nd }}(2.61)$ & $4^{\text {th }}(3.24)$ & $5^{\text {th }}(3.41)$ \\
Build Consensus & $3^{\text {rd }}(2.77)$ & $2^{\text {nd }}(2.56)$ & $1^{\text {st }}(2.53)$ \\
\hline
\end{tabular}

Comparing the superintendents' and teachers' rank ordering shows a wider spread. Teachers' and superintendents' rankings of the five leadership components were separated by at least two order rankings. Two items, articulating a mission and working with the school board have a difference of three order rankings. Superintendents ranked these two items first and second.

The rank orderings of the leadership components by teachers and principals were more closely related teachers' and superintendents', but none of the components were ranked at the same level of importance by teachers and principals. Articulating a mission showed three ranks of separation, assessing staff development two ranks, and the remaining items had one rank order of separation. I thought teachers and principals, because of their close working relationship, would be closely aligned in their perceptions of relative importance of the leadership components. 
It should be noted that the sixth item political bearing was purposely excluded from this part of the questionnaire that attempted to identify the most and least important leadership factors. I believe it is extremely important for superintendents to understand this role of knowing the constituents within the community we serve and to understand how that familiarity relates to decision making.

The political role of superintendents, compared with the other five leadership components, is the least understood by principals and teachers as it relates to their perception of the superintendents' role. My experience is that principals and teachers do not normally have the opportunity to observe the superintendent as s/he communicates with constituents at board meetings or in the community. If educational politics is the demonstration of a group's power, influence, and authority over valued resources, (Johnson 2003), then decisions made by the superintendent to satisfy pressure group concerns can directly impact the school and classroom. Principals and teachers are not usually involved in this part of political conversation, although they do participate in political conversation within the community. They may not attend board meetings, but they certainly influence the decisions of a superintendent.

The differences in perceptions of all five leadership areas indicate that superintendents and teachers view the impact on the learning environment of superintendent's various leadership roles quite differently. According to the narrative statements, the explanation for this difference is how superintendents relate to the instructional staff. Teaches expect superintendents to build consensus with them before beginning a new initiative or programmatic change. Teachers want to be involved and should have some say on what will be occurring in their classrooms. This shared sense of responsibility for the common good of the learner should be encouraged to grow (Trimble, 1996). Teachers want the superintendent to be knowledgeable about curriculum; they 
want the person who is in charge to have an understanding of the curriculum and how it relates to teaching and learning. Teachers ranked the leadership components of consensus building and curriculum knowledge as the most important for a superintendent who can effectively promote student achievement. Although teachers ranked these items as most important, superintendents perceived these areas as third and fourth in the ranking of importance.

The staff development leadership component stands out as one that teachers, principals, and superintendents ranked similarly in relative importance. Each group ranked the area of staff development as last or next to last in importance; however, teachers viewed staff development as more important than did superintendents and principals. Teachers and administrators use this instructional improvement strategy to improve teaching and learning in the classroom by improving their skills without having to return to formal schooling. As teachers restructure their classrooms within the constraints of staff development sessions, they are fearful the district office will ignore their needs (Trimble, 1996). The amount of money spent on staff development sessions is staggering. With all three groups indicating staff development as low in importance, the effectiveness of these staff development sessions should be questioned.

The superintendents' perception of the most important role for developing an effective learning environment is demonstrated by their top two rankings of the leadership components. To articulate a mission that establishes direction and purpose for the school system was ranked first by superintendents. This role articulates to the staff the priorities and needs as identified by the superintendent - the CEO of the organization (Rallis, Tedder, Lachman, \& Elmore, 2006). The superintendent needs to articulate the initiatives. To accomplish a system-wide initiative s/he must have the support of the school board. Superintendents perceived articulating a mission to be even more important than building consensus with the staff at the school district. Without 
articulating the mission and cooperatively working with the school board, superintendents perceived that it would be difficult to accomplish goals established with the instructional staff.

Consensus building is the leadership component that superintendents ranked as third in importance. Superintendents understand that building consensus is important because if they do not have the support of the staff, it is likely that very little will change in the classroom (Dufour, 2008). The reality of the superintendent position is that if superintendents hope to accomplish anything with the school district staff, they must first have the support of the school board, to advance programs and budget appropriations. School boards need to have an attitude of how can we improve academic achievement for all students and not be about battling the daily fires of the school system (A Report of the National School Boards Foundation, 1999). A superintendent's ability to effect change may be directly connected to the provisions within and the renewal of one's contract. Superintendents have had contracts shortened ( 2 1/2 year average) due to the tensions between elected and professional leaders and because of their inability to work with board members, principals or teachers in what is perceived as an effective manner (A report of the National School Boards Foundation, 1999).

The research conducted in this study indicates that teachers want superintendents to visit the classroom to observe firsthand the impact of teacher and learning. Teachers indicated in their narrative responses that they believe superintendents can learn what occurs in the classroom from school visits. Perry M. Smith quoted John F. Kennedy as saying that "leadership and learning are indispensable to each other" (Smith, 1998). The survey results indicate that teachers view the superintendent's knowledge of curriculum and development of a working relationship with teachers to aid in developing a clearer understanding of teaching and learning. It is quite clear from the research that teachers want the superintendent to be in the classroom to gain a 
better understanding of curriculum, of teaching and of the delivery of subject matter to the students. It is also clear to me that teachers view a superintendent's visit to the school and classroom and his/her receptiveness to the staff's input as important for the superintendent to gain a fuller understanding of what the teacher is "going through" in the classroom (Cunningham, 1985). The narrative responses indicated that teachers identified these needs because of their experiences with superintendents who relegated classroom visits and observations to other administrative employees and who cannot articulate curriculum initiatives.

The superintendents' and principals' perceptions of effectiveness are more aligned. Principals have more of an opportunity to collaborate and work directly with the superintendent and are considered to be a part of the administrative team. Superintendents may meet, at least monthly, with principals, providing direction and expressing expectations (articulation of mission) of what the superintendent hopes to accomplish. Systemic change targeting continuous improvement manifests certain key elements with strong leadership being foremost (Armstrong 2003). It is the responsibility of the principal to explain to and implement with teachers the superintendent's initiatives. The role of the principal can be directed to monitor those educational programs. Principals may not agree with the superintendent's direction, but they will continue to monitor and implement those initiatives in the classroom. In a sense, the principal may view his/her role as being the superintendent (CEO) within their own school: building consensus, creating staff development sessions, and articulating a mission for the school.

According to the results of the survey, it is clear that principals do not perceive the superintendent's role of working with the school board as very important. Principals, like teachers, may not see the interaction and relationship between the board and superintendent. Principals may understand that school boards make decisions recommended by the 
superintendent and that those decisions directly impact their school. Regardless, principals still perceived the superintendent's role of working with the school board as less important than three of the other leadership components.

I anticipated that teachers and principals would be more closely aligned than teachers and superintendents in their rankings of the importance of the leadership components. The survey results indicate that principals and teachers identify curriculum knowledge and consensus building as important. These two items were close, with one ranking of separation when comparing principals' and teachers' rankings. It is important for principals and teachers to have a good working relationship through consensus building. When curricula initiatives are presented at the school level, these programs need the support of the instructional staff who will be implementing these ideas. Teachers want the principal to be knowledgeable about curriculum. Teachers want to have confidence that their administrator understands current teaching practices. Educators want all students to learn at higher levels and realize the benefits of working collaboratively together (DuFour, 2005).

When comparing teachers' and principals' view of assessment of staff development and articulating a mission, the rank ordering differed by at least two. Principals' and teachers' perceptions were clearly different regarding these two items. The survey results identify teachers' perception that it is important for the superintendent to spend time in the classroom if the superintendent is to contribute to a creative learning environment. Understanding the mission as it relates to instruction is important for the teacher to move forward. This clear vision can give purpose and ensure that everyone is accomplishing similar goals (Fullan, 2001). Principals expect that the superintendent to articulate the district mission to ensure that each school is moving in a similar fashion. 
Teachers and principals ranked the leadership role of the superintendent working with the local school board as least important. This outcome is not surprising, because neither teachers nor principals work directly with the school board, nor do they answer directly to the board members as the superintendent does. The opportunity to work with the board directly is minimal for principals and teachers. The influence of school board members in this state, by law, has authority only over one person, the superintendent. All other professional personnel must be recommended to the school board by the superintendent before they can be hired or released. A local school board only has authority when the members of the board are seated at a meeting and a quorum is present. A school board member does not have authority to make decisions outside the purview of a meeting. School board members may visit schools and classrooms and may talk to personnel to gain an understanding of what is occurring within the schools, but they have no direct authority within the schools. Accordingly, the research indicates that teachers and principals perceive the superintendent's leadership role of working with the school board as less important than other leadership components in creating an effective learning environment.

Superintendents are directly accountable to the school board. Unless teachers and principals attend school board meetings (or read the newspaper accounts or minutes of the meetings) they do not see the interactions between their superintendent and the school board members. Teachers and principals may not understand the accountability a superintendent has to the school board. Each decision made by the superintendent potentially impacts his/her ability to perform within the job. The superintendent must perform to meet expectations. Teachers and principals might not attend board meetings and they might not see the dynamics of school board members with the superintendent and how that interaction influences decisions between both entities. Perception is reality for a superintendent as this survey indicates. The superintendent 
understands his/her role and the role of the school board as it directly impacts the performance of the superintendent.

The leadership subscale mean rankings by respondent role have been averaged in Table 10 to present another view of the relative importance of the five leadership items. Averaging the mean rankings of the of the leadership components as such assumes hypothetically that superintendents', principals', and teachers' rankings all receive equal weights. Therefore, this averaging explores a different perception of the importance of the leadership components and gives a hypothetical overall ranking of the importance of the leadership components.

In this hypothetical overall ranking, building consensus is the most important leadership component. The articulation of mission is the second most important, and staff development is the least important leadership factor. 
Table 10

Leadership Components' Relative Importance Ranking by Total Mean

\begin{tabular}{lccccc}
\hline \multicolumn{1}{c}{ Leadership Component } & Sup. & Prin. & Teach. & Tot. Mean & Ranking \\
\hline Assess staff development & 3.76 & 3.69 & 3.14 & 3.53 & $5^{\text {th }}$ \\
Articulate mission & 2.59 & 2.35 & 3.18 & 2.71 & $2^{\text {nd }}$ \\
Display curriculum knowledge & 3.16 & 3.08 & 2.64 & 2.96 & $3^{\text {rd }}$ \\
Work with school board & 2.61 & 3.24 & 3.41 & 3.09 & $4^{\text {th }}$ \\
Build consensus & 2.77 & 2.56 & 2.53 & 2.62 & $1^{\text {st }}$ \\
\end{tabular}

Note: Sup. $=$ superintendent Prin. $=$ principal; Teach $=$ teacher; Tot. Mean $=$ total mean.

Comparing this overall ranking of the leadership components to the superintendents' ranking shows a difference in the rank order of four of the five items. The ability to assess staff development remains the least important, and articulating a mission remains a high choice for superintendents. Teachers' rankings differed from the overall ranking in four of the five components as well, with consistent top ranking of building consensus. Principals' ranking of the leadership elements align more closely with the overall ranking; three of the principals' rankings matched the overall ranking - display curriculum knowledge, work with school board and assess staff development..

This table does not address any of the research questions within this dissertation, but by hypothetically weighting superintendents', principals' and teachers' rankings equally, an overall perceived importance of the leadership components can be explored. In future follow up studies this could be an important element to explore.

Narrative statements from this study indicate that if a superintendent wants "buy in" from staff as educational initiatives are introduced, teachers need to be included in the decisionmaking process. One way to for superintendents to build consensus with teachers and principals 
is to include teachers and principals in the decision-making process through professional learning communities. Empowering professionals through such efforts enhances the opportunity for principals and teachers to be directly involved at both the county and school level (DuFour, 2008).

Future implications.

An immediate goal and recommendation for superintendents is to make frequent classroom visits. Visits should be more than a "pop-your-head-in variety"; rather a visit in which the superintendent is involved with the instructional learning environment. I will develop a schedule that puts me into every school to talk directly with teachers and principals, within the learning communities, about the different initiatives we are expecting to accomplish in the classroom, and I will seek input from the instructional staff to determine the effectiveness of our educational programs. I will make it a priority to listen to the feedback given by the teachers and principals as suggested changes are considered.

A long-term goal I recommend for superintendents is twofold: (a) develop a process of consensus building between teachers, principals and superintendents; and (b) become more mindful of the curriculum and teaching in order to develop a content knowledge, and effective teaching/learning strategies, as it will be delivered by the instructional staff. The amount of decision making that superintendents deal with daily encourages them to delegate responsibility to personnel assigned to the district office. With all the other responsibilities superintendents attend to, it is difficult take the time to comprehend all of the latest information and knowledge concerning curriculum. Consequently, superintendents need to make concentrated efforts to develop a greater understanding of content and how it relates to instruction and to trust the district office staff in professional development, monitoring and follow up. 
Staff development sessions are needed to retrain the instructional staff in educational strategies to address the 21 st century learner. The survey results indicated that this item was ranked low by each participating group. If superintendents value the importance of staff development and the importance it plays within the school system, they will need to ensure it is effective for those personnel directly involved. Within the next few years superintendents will be challenged to identify methods to deliver staff development that is considered meaningful to the classroom teacher and principal. Evaluation of staff development sessions is needed to gain insight into why this item was ranked low by principals and teachers. In addition to assessing the value of given training sessions, superintendents should evaluate the processes by which the training sessions are chosen. It is possible that teachers and principals would rank staff development higher if they had more input into the decision-making process regarding what training is needed within their own schools.

The survey indicated that many teachers and administrators already hold advanced degrees, making it paramount for superintendents to provide significant and long lasting on-thejob training and staff development. The one day in-service, at the beginning of the year, may not be enough to effect change. As I visited in-service sessions this summer, teachers who attended multiple day trainings felt some sessions were long and arduous but extremely worthwhile. Teachers were encouraged to see the superintendent at these staff development sessions. These teachers thought that I would have a broader understanding of what occurs in the classroom between teacher and student because of my attendance at these sessions.

\section{Comparing teachers' and principals' perspectives.}

Is there a statistically significant difference comparing teachers' perceptions of their superintendent with the perception of their respective supervising principal in the same work 
location? A related sample $t$ test did not show significance in any of the six leadership components that were measured. I had anticipated a likeminded response between teachers and principals who worked together. I thought the survey would indicate that teachers and principals who work together would have similar responses within the six areas.

The non-significant results may be due to a limitation of the study: there were only 23 ordered pairs of principal and teachers in the principal's school. This is not necessarily a sufficient sample size to determine significance. The difficulty in gathering a larger number of principal-teacher pairs centered on several reasons:

1. Many of the participants did not indicate a work location or school district when asked to identify the county in which they worked as an educator.

2. The survey did not ask respondents to identify the school where they work. I realize giving this information could have been problematic for some of the participants who expressed concerned about their identity being compromised. This worry could have caused 20 of the participants to begin the survey only to quit after answering just a few questions. Assuring the respondents that strict anonymity of their responses would be maintained did not allay concerns for 20 respondents. Loss of data from these 20 respondents may have reduced the number of principal-teacher pairings for inclusion in the data analysis.

3. Those participants that did give a school location may not have indicated the programmatic configurations making it difficult for the statistician to match teacher and principal from the same location. School names in some of the school districts are similar between programmatic levels such as elementary, middle or high school. When a participant indicated the school name without indicating programmatic level 
the statistician had a difficult time matching participants from a similar location if it did not contain the exact school level.

Several other factors that may have contributed to a lack of significance for this hypothesis;

1. Only 126 of the 360 identified Nationally Board Certified Teachers in the state of West Virginia responded to the survey. The number of eligible participants was reduced because 22 individuals who worked in my school district were not included as prospective participants. The research may have been compromised if the Nationally Certified Teachers from my school district felt compelled to respond, particularly if they thought their confidentiality was not protected. In addition, they may have responded to what I expected rather than portray their true feelings.

2. Likewise, the number of available administrators (700) who could have participated in the survey was reduced by 19 , because the principals from my school district were not included in the study. Excluding educators from my school district may have decreased the number of principal-teachers pairs in the analysis. Many of the administrators from my school district knew that I was working on my doctorate and asked me if they could participate. Once again, I felt their responses might be influenced by what they perceived I expected and might not reflect their perceptions, resulting in invalid results.

3. 14 of the 360 Nationally Certified Teachers no longer work in a classroom and are no longer assigned to a school or working in conjunction with an administrator. This was evident in the survey by those teachers listing "other" as their present assignment. 
Several Nationally Certified Teachers, having moved to a district-level position, had assumed a change in job title and responsibilities.

4. Not all schools have nationally certified teachers, yet all schools have a principal, so principal-teachers pairings were impossible for these schools.

5. Several Nationally Certified Teachers may be assigned at the same school, thereby reducing principal-teacher pairings in the study.

\section{Implication of the narrative results.}

Two narrative prompts were used to encourage participants to add additional information that they felt would be relevant to this survey. The first narrative question solicited information for ideas that the participant believes contributed to the efficacy of a superintendent but that were not already included as a part of the survey: Are there any other factors that were not addressed in this survey that you believe contribute to a superintendent efficacy? If so, please describe them in the area designated on the survey.

Major themes expressed by 86 respondents are communication; create leaders, intelligence, experience, district cultural, visionary leader, and proximity. Even though communication was addressed within the survey, respondents felt communication beyond articulation of mission and vision was important. The respondents felt the communication exhibited by the superintendent should emphasize the positive aspects of the school system. They wanted the superintendent to communicate regularly with staff and demonstrate listening skills. This personal contact with staff members and a superintendent's ability to understand because s/he is willing to listen were strong themes expressed by the respondents. The comment that expresses this paramount theme was, "I believe All administrators at All levels should be IN 
SCHOOL BUILDINGS/IN CLASSES/TALKING...no LISTENING to teachers and students-

HEARING what we who are 'in the trenches' understand to be OUR needs-not what the central office THINKS our needs are."

With a majority of the respondents commenting in some way about wanting the superintendent to not only talk, but also to listen to the needs of the staff emphasizes the need to be involved with the "people in the trenches." Some of the respondents felt the superintendent is out of touch with the "needs of the school." This research indicates that the superintendent needs to be involved at the school with the staff. I am certainly not purporting that the superintendent micro-manage the school; however, the superintendent needs to regularly visit schools to see firsthand what is occurring. "If subordinates or people in general, know that they genuinely have easy access to their leader, they tend to view the leader in a more positive, trustworthy light" (Phillips, 1992). I realize the demands of the job does not lend itself to always visiting the schools as much as we would like, and I am also keenly aware that we are not always received positively, but it certainly appears through this research that educators want us to be proactive by being a part of the school. Merely knowing of the superintendent is not sufficient; teachers want contact with the superintendent.

The second narrative question solicited information regarding any other ideas, other than those listed in the survey, that the participant believe contributed to the efficacy of a superintendent: Please use the space below to make any additional comments regarding factors that contribute to a superintendent's efficacy or any other issues germane to this survey.

Major themes expressed by 53 respondents to this question pertained to effective or ineffective leadership, morale, and relationships. Many of the respondents also took the opportunity to submit negative comments about their superintendents. This could have been one 
of the reasons so many worried about the confidentiality of the comments. The assurances given to them by the examiner and the trust of confidentiality encouraged several respondents to express their candid views.

Several respondents expressed comments about the superintendent being an effective leader - through decision making and through selecting competent staff to work at the district level. One comment directly reflects what several respondents indicated "The superintendent must be able to delegate to his assistants, curriculum supervisors, directors because s/he can't do everything and capacity building is, in my opinion, what is most important. Empowering staff to take the lead and monitoring the staff, especially with regard to curriculum and staff development, are ways to ensure accountability while allowing the superintendent to perform his/her many duties associated with the job."

A second and more pronounced theme that emerged from this question was negativity regarding the superintendent. Respondents' remarks ranged from the superintendent's "encouraging a toxic culture" to a statement from a teacher indicating that if s/he "never sees him or her in the school building on a casual basis there will be no perception of his caring or knowledge about the school or it students, no matter how effectively he runs a meeting or voices a "vision statement" to the board or through a newsletter."

The responses to this second narrative question are rooted in each particular school and school district, where the superintendent is perceived as an effective or an ineffective leader. Participants' comments for this question ranged from a superintendent addressing moral concerns to the superintendent's ability to build collaboration. It is obvious to me that the respondents want a superintendent to be someone who does more than just work with the school board. The respondents are looking for someone who is "ethical" and strives to do the "right 
thing". They want the "good ole boy" system of promotions replaced with one of hiring the best qualified candidate for the position. The respondents indicated that a superintendent should be someone who has "plenty of positive and productive face to face interactions with students, teachers, principals and community members. First you have to prove you care." Glaser (2006) notes that this leader who "leads through personal relationships rather that by positional power creates an environment for open, honest communication where people support and learn from each other." Additional responses from this second question expressed an understanding of the burdens associated with the superintendent's position and the superintendent's ability to not lose sight of one fundamental purpose, the education of the children.

These comments reveal participants' perceptions of their own superintendents within their school districts. $39 \%$ of the survey respondents chose to write a narrative response. These 139 individuals felt strongly enough about a particular item or theme to express themselves in narrative form. The overall themes of involvement, communication, and the selection of staff indicate that the respondents wanted to express their views about the efficacy of a superintendent regarding the development of an effective learning environment. It can be difficult to solicit respondents to write a response by filling in a blank space. When those individuals respond in writing to a prompt in a survey, I believe it indicates that they have a strong opinion about a particular question that they wish to express.

\section{Additional Research}

I chose to compare the perceptions of teachers and principals in the state. Future research could focus on comparing perceptions of principals and superintendents or superintendents and teachers in the same district. Would the perceptions of principal or teachers at different programmatic levels be significantly different if compared to one another? I encourage future 
measurement and comparisons of the perceptions of elementary-trained principals and teachers with secondary-trained principals and teachers to determine if there is a significant difference in their perceptions of the superintendent as s/he works to achieve an effective learning environment.

Would the comparative information between teachers, principals and superintendents show a significant difference if the school district was larger or smaller than 5000 students? Does the smaller school system create opportunities for the superintendent to be in the classroom more often than the superintendent of a larger school district? Will there be a significant difference in educators' perceptions of leadership components in larger school districts having student populations over 10,000? Will a larger staff to assist the superintendent to visit schools and classrooms make a difference as the superintendent develops an effective learning environment?

Requesting participation by assistant principals within the survey group of administrators would increase the likelihood of more pairs participating in the survey. A potential hypothesis of surveying assistant principals could be the perceptions they hold, in comparison to the principal. This could make for an interesting study by examining the viewpoints of the principal, the assistant principal, and the teacher using the same six points of the survey. The hypothesis could test for significance regarding the assistant principal's perceptions of the superintendent compared to the principals and teachers assigned to the same school. Are the assistant principals' overall perceptions different than the principals' or teachers' regarding relative ranking of the superintendent leadership components?

I suggest that school board members be included in the population sample in subsequent research. In West Virginia, this pool of 275 additional prospective participants will add a perspective that is unique from other sampled groups. Board members are responsive to the 
community. Their perception of the school district's enacted policies and budget allocations is unique and can provide insight about the superintendent's role that complements the perspectives of the district's educators. The superintendent is responsive to the board members and will act on their decisions. The school board's perception of the superintendent is derived from its monthly meetings and from feedback from the community. School board members' responses may be quite different from the employees in the field.

An additional research project could focus on the effects of developing an effective learning environment with the constraints of political bearing. Many factors within the community put pressure on educational resources. The research could look at a school district to determine if one part of the district is more or less affected by political pressures. Does one school receive more educational resources because of this pressure? Do board members represent the entire school district, or does political bearing cause board members to favor the area of the district that they represent?

Future research should include studies that explore further the effectiveness of staff development in creation of an effective learning environment. In this study, staff development was ranked lowest by principals and superintendents and next to last by the teachers. This consistently low ranking of staff development calls into question staff development as a tool to effectively retrain staff. Does the amount of money spent in Title I, II, and IDEA on staff development have the impact many believe? In light of the importance that teachers and principals in this study placed on consensus building, future studies related to the effectiveness of staff development should take into account varying levels of teachers' and principals' involvement in the choosing and implementing staff development activities in their school district and in their schools. 
As stated, this research indicated that teachers', principals' and superintendents' perceptions of the relative importance of the five leadership components included in this study can be quite different from one another. If this questionnaire were expanded to consider several more leadership skills, would the disparity of perception among the participants be even greater? Should a survey consider the superintendent's role as a business leader who addresses the financial bottom line?

The education of children is changing to address the needs of the $21^{\text {st }}$ century learner. In the next ten years, education will continue to evolve and a school district needs a superintendent who is willing to involve stakeholders who can make a difference. Perhaps future research should determine if a difference exists between the superintendents from an educational background and those with business training.

One improvement I recommend if this survey is utilized again is to provide a drop-down menu identifying the school location of employment and a drop-down menu listing the school district of employment. This will make it easier to analyze comparative data.

Future research participation requested of West Virginia K-12 educators could encourage each participant from the same building location, by letter, to make requests of similarly certified educators at the same location to respond to the survey. Educators should be assured that no one other than the statistician will see their responses. Anonymity in research studies that may affect one's career is crucial to acquiring meaningful survey results. It must be noted again that anonymity was a concern for many of those participating. Several asked the statistician about the protection of their identity and how they could be assured of this protection. Any future research asked of these participants must continue to assure confidentiality. 


\section{Recommendations}

Superintendents need to think carefully as they attempt to enact change in a school district. They should pay close attention to the recommendations of teachers and school administrators. I was disheartened to see from this research that teachers' and superintendents' perceptions were quite different. I was heartened with the new information, believing that with new knowledge effective change can be made. Teachers want the superintendent's leadership skills to be strong in areas that affect them in the classroom - knowledge of the curriculum and demonstration of collegial relationship. Teachers want a superintendent that is not out of touch with the classroom. I, too, believe more frequent communication in the form of school visits and conversations with staff will be helpful in our school reform efforts. I have included in my schedule next year many more school and classroom visits that put me directly in the room with the teachers. I want to see firsthand the teacher interaction with the student and to hear firsthand teachers' concerns. Providing an opportunity to build a co-creative environment encourages problem solving and encourages individual talents to emerge (Glaser, 2006).

Teachers and principals need to be included at the planning stage before beginning any new initiative. The value of including all stakeholders in the decision-making process will help the success rate and the implementation process of new incentives. I am hopeful this survey will indicate to superintendents that the perceptions of teachers and principals are sometimes different from their views and those teachers' and principals' views need to be considered. Teachers and principals implement decisions made by the superintendent and the board of education. If teachers and building-level principals are not a part of providing input into the process that they are being asked to implement, and if they are not vested in the change, I believe the probability of success is diminished. 
The superintendents can be that person who makes a difference by being instrumental in the creation and development of an effective learning environment. This task needs to be accomplished with teachers, administrators and board members supporting the educational goals of the district. Educating the youth should not be done in isolation, but should be accomplished by all stakeholders. If stakeholders act independently from one another, the chance of success diminishes.

We all want to- - and often dream of-leaving a legacy in our professional careers. What better way for a superintendent to realize that dream than by making a difference in the educational lives of students by creating an effective learning environment where student success is available to all students. The reality of this dream is that it can be achieved, but not alone. The true legacy for all educators should be that we made a difference by working together for each and every student. 


\section{References}

Aguerrebere, J. A. (2008). New report affirms national board certification's positive impact on student achievement and learning. Retrieved January 17, 2008, from http://www.nbpts.org/about_us/news_media/press_releases?ID=422

American Association of School Administrators (1993). Professional standards for the superintendency. Arlington, VA: Sans Serif Graphics.

Armstrong, S. (2003). Systemic change, continuous improvement. Retrieved from http://www.ciconline.org/home

Bjork, L. G., Kowalski, T. J. (2005). The contemporary superintendent. Thousand Oaks, CA: Corwin Press.

Bjork, L. G., Kowalski, T. J., \& Young, M. (2005). National education reform reports: Implications for professional preparation and development. In L. G. Bjork \& T. J. Kowalski (Eds.).

Barth, R. S. (2006). Improving relationships within the schoolhouse. Association for Supervision and Curriculum development, 9-13.

Bennis, W. \& Nanus, B. (1985). Leaders: The strategies for taking charge. New York: Harper \& Row.

Bluman, A. G. (2007). Elementary statistics: A step-by-step approach (6 ${ }^{\text {th }}$ ed.). Boston: McGraw Hill.

Bolman, L. \& Deal, T. E. (1997). Reframing organizations: Artistry, choice, and leadership (2 ${ }^{\text {nd }}$ ed.). San Francisco, CA: Jossey-Bass, Inc.

Callahan, R. E. (1967). The superintendent of schools: An historical analysis. Final Report of Project S-212 Cooperative Research Branch U. S. Office of Education Department of Health, Education and Welfare. (ERIC Document Reproduction Service No. Ed 010410). 
Cohen, M. D. \& March, J. G. (1989). Leadership and ambiguity: The American college president. Boston: Harvard Business School Press.

Crowson, R. \& Morris, V. C. (1991). The superintendency and school leadership. Advances in Educational Administration. 2, 191-215.

Cuban, L. (1985). Conflict and leadership in the superintendency. Phi Delta Kappan: The Professional Journal for Education, 67, 28-30.

Cuban, L. (1988). How schools change reforms: Redefining reform success and failure. Teachers College Record, 99(3), 453-477.

Cunningham, L. L. (1985). Leaders and leadership: 1985 and beyond. Phi Delta Kappan: The Professional journal for Education, 17-20.

Deal, T. E. \& Peterson, K. D. (1999). Shaping school culture: The heart of leadership. San Francisco, CA: Jossey-Bass, Inc.

Doyle, D. P. \& Hartle, T. W. (1985). Leadership in education governors, legislators, and teachers. Phi Delta Kappan: The Professional journal for Education, 21-27.

DuFour, R., Eaker, R. \& DuFour, R. (2005). On common ground, the power of professional learning communities. Bloomington, IN: National Educational Service.

DuFour, R., Eaker, R. \& Dufour, R. (2008). Revisiting professional learning communities at work. Bloomington, IN: Solution Tree.

Edmonds, R. R. (1979), October. Effective schools for the urban poor. Educational Leadership, $37,15-27$.

Executive Leadership (2007). The 8 keys to leadership greatness. Falls Church, VA: Random House.

Fullan, M. (2001). Leading in a culture of change. San Francisco, CA: Jossey-Bass, Inc. Fullan, M. (2008). School leadership's unfinished agenda. Education Week, 27, p. 36-28. 
Glaser, J. E. (2006). The DNA of leadership. Avon, MA: Platinum Press.

Glass, T.E. (1992). The 1992 study of the American superintendency: America's education leaders in a time of reform. Arlington, VA: American Association of School Administrators.

Griffiths, D. E. (1966). School superintendent. New York: The Center for Applied Research in Education, Inc.

Herman, J. J. \& Stephens, G. M. (1989). The four keys necessary for instructional leadership. NASSP Bulletin, 73, 55-59.

Johnson, R. (2003). Those nagging headaches: Perennial issues and tensions in the politics of education field. Educational Administration Quarterly, 391(1), 41-67.

Johnson, S. M. (1996). Leading to change: The challenge of the new superintendency. San Francisco, CA: Jossey-Bass, Inc.

Kotter, J. P. (1985). Power and influence: beyond formal authority. New York: Free Press.

Kowalski, T. J. (1999). The school superintendent: theory, practice, and cases. Upper Saddle River, New Jersey: Prentice-Hall, Inc.

Laswell, H. (1958). Politics: Who gets what, when and how. Cleveland, OH: Meridian Books. Leadership matters: transforming urban school boards (1999). A Report of the National School Boards Foundation. The National School Boards Foundation, Alexandria, Virginia.

Lezotte, L.W. (n.d.). Revolutionary and evolutionary: The effective schools movement. Retrieved from http://www.effectiveschools.com/images/stories/RevEv.pdf

Mish, F. C. (Editor in Chief) (1997). Merriam Webster's collegiate dictionary $\left(10^{\text {th }}\right.$ ed.) Springfield, MA: Merriam-Webster, Incorporated.

National Staff Development Council. (2005). A study of professional development for public school Educators in West Virginia, 11-26. 
Nelson, D. (1974) Scientific Management Systematic Management \& Labor-1880-1915. The Business History Review, Vol.48 No.4 (winter, 1974) pp. 479-500.

Ogawa, R. T. \& Bossert, S. T. (1995). Leadership as an organizational quality. Educational Administration Quarterly, 31 (2), 224-243.

Phillips, D. T. (1992). Lincoln on leadership: Executive strategies for tough times. New York: Warner Books, Inc..

Paine, S. L. (2006). Framework for high performing $21^{\text {st }}$ century school systems. West Virginia $21^{\text {st }}$ Century leadership, 1-5.

Peterson, K. D. (2002, Summer). Positive or Negative. National Staff Development Council, 1113.

Peterson, K. D. (2001, Winter). The roar of complexity. National Staff Development Council, 1821.

Petracca, M.P. (1992). The rediscovery of interest group politics. In M.P. Petracca (Ed.), Politics of interest: interest groups transformed (pp. 3-31). Boulder, CO: Westview.

Rallis, S., Tedder, J., Lachman, A. \& Elmore, R. (2006). Superintendents in classrooms: From collegial conversation to collaborative action. Phi Delta Kappan: The Professional Journal for Education, 537-543.

Ravitch, D. (2007, February 25). Challenges to teacher education. Address to AACTE, 14-19.

Smith, P. M. (1998). Rules \& tools for leaders. Garden City Park, NY: Avery Publishing Group.

Stover, D. (2009). Out of control. American School Board Journal, 196, (3), 15-18.

SurveyMonkey.com (1999). SurveyMonkey [Online survey tool]. Accessed at http://SurveyMonkey.com

Trimble, K. (1996). Building a learning community. Equity and Excellence in Education, 29 (1), 37-40. The University of Massachusetts School of Education Quarterly. 
Tyler, R. (1947). Basic Principles of Curriculum and Instruction. University of Chicago Press.

Waters, J. T. \& Marzano R. J. (2007). The Primacy of Superintendent Leadership: The School Administrator, March, pp. 10-16

Wickersham, M. E. (2009). Leading by example: High Ethical expectations foster trust in schools: American School Board Journal, 196, (3), 20.

York-Barr, J., Sommers, W. A., Ghere, G. S. \& Montie, J. (2001). Reflective practice to improve schools: An action guide for educators. Thousand Oaks, CA: Corwin Press, Inc.

Zaleznik, A. (1992). Managers and leaders: Are they Different? Harvard Business Review, 126135. 
Appendix A - Superintendent Efficacy Questionnaire

\section{Superintendent Efficacy Questionnaire}

\section{Devono, Díaz, \& Callejo Pérez (c) 2008-2009}

1. Please choose your current role.
Superintendent
Administrator
Teacher

2. Please choose from the drop down menu the county in which you work as an educator.

3. Please select the type of school in which you serve as either Teacher or Principal.

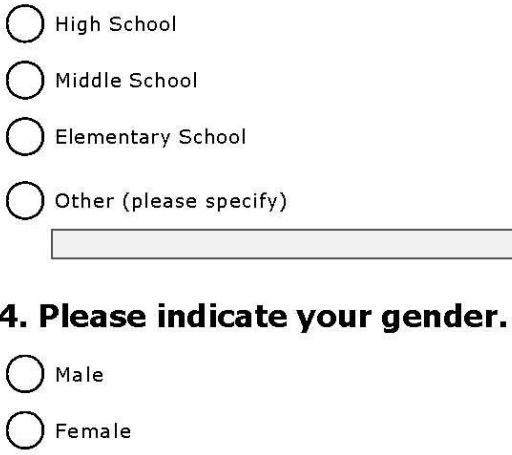

5. Please indicate the highest level of formal education you have earned.

Bachelor's Degree

Master's Level Degree

Doctoral Degree

6. If you are a Teacher or Principal, please enter the name of the school in which you work (leave this item blank if you are a Superintendent). 


\section{Superintendent Efficacy Questionnaire}

\section{Superintendent Efficacy Questionnaire Items}

\section{Please indicate your level of agreement with the following statements as they} relate to your school district by choosing the appropriate response.

The Superintendent is aware of teachers' staff development needs within the
district.
In our district, teacher staff development results in improved teaching and
learning in the classroom.
In our district, administrator staff development results in improved teaching
and learning in the classroom.
The Superintendent adequately assesses teachers' staff development needs
within the district.
The Superintendent is aware of administrators' staff development needs within
the district.
The Superintendent adequately assesses administrators' staff development
needs within the district.

8. Please indicate your level of agreement with the following statements as they relate to your school district by choosing the appropriate response.

ur mission and/or vision helps the school district clarify its priorities.
he Superintendent clearly articulates the mission and/or vision to the
ommunity served by our district.
can clearly articulate to others our district's mission and/or vision statement.
ur mission and/or vision helps set the direction for the school district.
he Superintendent clearly articulates the mission and/or vision to school
istrict personnel.




\section{Superintendent Efficacy Questionnaire}

\section{Superintendent Efficacy Questionnaire Items}

9. Please indicate your level of agreement with the following statements as they relate to your school district by choosing the appropriate response.

The Superintendent has little impact on curriculum and teaching within our
district.
The Superintendent demonstrates knowledge of curriculum and teaching
theory.
The Superintendent guides curriculum and teaching to enhance learning in the
classroom.
The Superintendent demonstrates knowledge of how curriculum and teaching is
practiced within our classrooms.

10. Please indicate your level of agreement with the following statements as they relate to your school district by choosing the appropriate response.

The Superintendent works effectively with the local school board.
The Superintendent is an advocate of students with the local school board.
The school board values the views of the Superintendent.
The Superintendent works well with the school board to carry out initiatives in
The Superintendent communicates effectively the concerns of the local school
board to teachers, administrators, staff and students.
The Superintendent advocates the needs of teachers, administrators, and staff
with the local school board.




\section{Superintendent Efficacy Questionnaire}

\section{Superintendent Efficacy Questionnaire Items}

11. Please indicate your level of agreement with the following statements as they relate to your school district by choosing the appropriate response.

The Superintendent's leadership style matches well with the needs of the
school district.
The Superintendent's leadership style builds consensus within the community.
The Superintendent has an effective leadership style.
The Superintendent's leadership style builds consensus among administrators.
The Superintendent's leadership style builds consensus among teachers.

12. Please rate the relative importance of each of the following items as they relate to contributing to the overall effectiveness of a school Superintendent.

$\begin{array}{ccc}\text { Not at All } & \text { Somewhat } \\ \text { Important } & \text { Exportant } & \begin{array}{c}\text { Impoly } \\ \text { Important }\end{array} \\ 0 & \bigcirc & \bigcirc \\ 0 & \bigcirc & \bigcirc \\ \bigcirc & \bigcirc & \bigcirc \\ \bigcirc & \bigcirc & \bigcirc \\ \bigcirc & \bigcirc & \bigcirc \\ 0 & \bigcirc & \bigcirc\end{array}$

The Superintendent's staff development choices impact teaching and learning in the classroom.

The Superintendent clearly articulates a mission and/or vision that establishes priorities for the school district.

The Superintendent's ability to work with the local school board facilitates policy and education initiatives.

The Superintendent's knowledge of curriculum and teaching enhances teaching and learning

The Superintendent is able to assess staff development needs.

The Superintendent's demonstration of a leadership style builds consensus within the schools and local community.

The Superintendent is able to work with the school board within the budget. 
Superintendent Efficacy Questionnaire

\section{Superintendent Efficacy Questionnaire Items}

13. Please rank the relative importance of each of the following items as they relate to a Superintendent's effectiveness. Rank as "1st Most Important Factor" the item that is most important with respect to a Superintendent's overall effectiveness. Rank as "2nd Most Important Factor" the item that is the second most important factor, etc., and rank as "Least Important Factor" the item that is the least important with respect to a Superintendent's effectiveness.

The Superintendent's demonstration of knowled ge of curriculum
and teaching to enhance teaching and learning.
The Superintendent's ability to clearly articulate a mission and/or
vision that establishes direction and priorities for the system.
The Superintendent's demonstration of a leadership style that
builds consensus within the schools and local community.
The Superintendent's ability to work with the local school board to
facilitate policy and education initiatives within the budget.
The Superintendent's ability to assess staff development needs
within the system to impact teaching and learning in the
classroom.

14. Please indicate your level of agreement with the following statements by choosing the appropriate response.

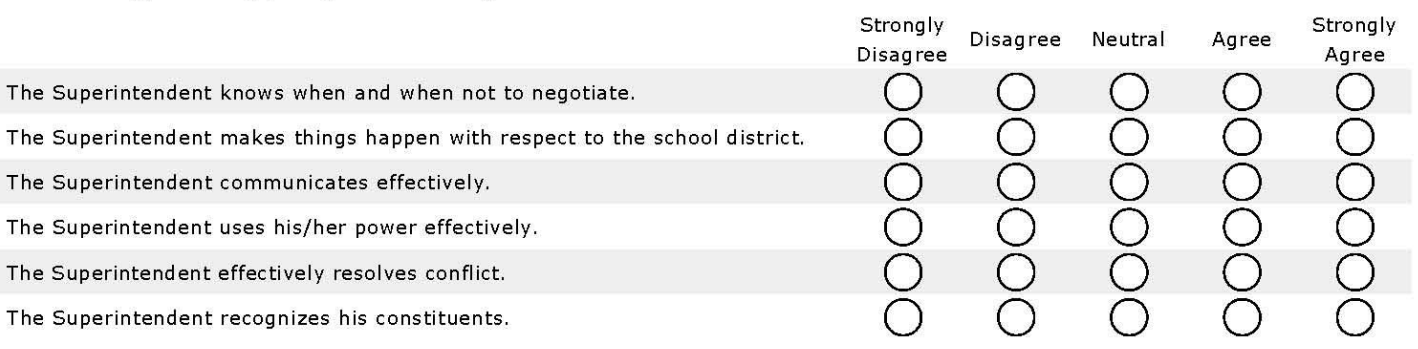

15. Are there any other factors that were not addressed in this survey that you believe contribute to a superintendent's efficacy? If so, please describe them in the space below.

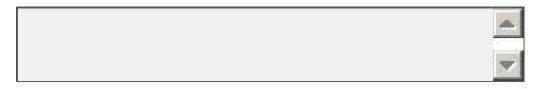

16. Please use the space below to make any additional comments regarding factors that contribute to a superintendent's efficacy or any other issues germane to this survey. 
Appendix B - Descriptive Statistics

\begin{tabular}{|c|c|c|c|c|c|}
\hline Subscale & $N$ & Mean & $s d$ & Minimum & Maximum \\
\hline $\begin{array}{l}\text { Ability to assess staff } \\
\text { development needs }\end{array}$ & 363 & 2.68 & 0.489 & 1 & 3 \\
\hline $\begin{array}{l}\text { Ability to impact classroom by } \\
\text { staff development choices }\end{array}$ & 362 & 2.75 & 0.450 & 1 & 3 \\
\hline $\begin{array}{l}\text { Articulation of mission and/or } \\
\text { vision }\end{array}$ & 362 & 2.83 & 0.410 & 1 & 3 \\
\hline $\begin{array}{l}\text { Knowledge of curriculum and } \\
\text { teaching }\end{array}$ & 363 & 2.78 & 0.428 & 1 & 3 \\
\hline $\begin{array}{l}\text { Ability to work with school } \\
\text { board on policy and education } \\
\text { initiatives }\end{array}$ & 363 & 2.85 & 0.379 & 1 & 3 \\
\hline $\begin{array}{l}\text { Ability to work with the school } \\
\text { board within the budget }\end{array}$ & 363 & 2.86 & 0.361 & 1 & 3 \\
\hline $\begin{array}{l}\text { Demonstration of consensus- } \\
\text { building leadership style }\end{array}$ & 362 & 2.83 & 0.401 & 1 & 3 \\
\hline Role of Respondent & 417 & 2.20 & 0.607 & 1 & 3 \\
\hline
\end{tabular}

